\title{
Sectoral approaches to improve regional carbon budgets
}

\author{
Pete Smith • Gert-Jan Nabuurs • Ivan A. Janssens • \\ Stefan Reis • Gregg Marland • Jean-François Soussana • \\ Torben R. Christensen • Linda Heath • Mike Apps • \\ Vlady Alexeyev • Jingyun Fang • Jean-Pierre Gattuso • \\ Juan Pablo Guerschman • Yao Huang • Esteban Jobbagy • \\ Daniel Murdiyarso • Jian Ni • Antonio Nobre • \\ Changhui Peng • Adrian Walcroft • Shao Qiang Wang • \\ Yude Pan • Guang Sheng Zhou
}

Received: 18 August 2006 / Accepted: 7 November 2007 / Published online: 29 January 2008

(C) Springer Science + Business Media B.V. 2007

\begin{abstract}
Humans utilise about $40 \%$ of the earth's net primary production (NPP) but the products of this NPP are often managed by different sectors, with timber and forest products managed by the forestry sector and food and fibre products from croplands and grasslands managed by the agricultural sector. Other significant anthropogenic impacts on
\end{abstract}

P. Smith $(\bowtie)$

School of Biological Sciences, University of Aberdeen, Aberdeen AB24 3UU, UK

e-mail: pete.smith@abdn.ac.uk

G.-J. Nabuurs

ALTERRA, Wageningen University \& Research Centre,

PO Box 47, Wageningen NL-6700 AA,

The Netherlands

I. A. Janssens

Department of Biology, University of Antwerp, Universiteitsplein 1, Antwerp 2610, Belgium

S. Reis

$\mathrm{CEH}$, Centre for Ecology and Hydrology Edinburgh, Penicuik, Bush Estate, Penicuik, Midlothian EH26 0QB, UK

G. Marland

Environmental Sci. Div., Oak Ridge National Lab, POB 2008, Oak Ridge, TN 37831-6335, USA

G. Marland

Ecotechnology Program, Mid Sweden University, 83125 Östersund, Sweden

J.-F. Soussana

Agronomy Unit, INRA, 234 Ave Brezet, Clermont Ferrand 63100, France

T. R. Christensen

GeoBiosphere Sci Ctr, Phys Geog and Ecosyst Anal, Lund University,

Solvegatan 12, Lund 22362, Sweden 
L. Heath

US Forest Serv, USDA, NE Res Stn, POB 640, Durham, NH 03824, USA

M. Apps

Canadian Forest Service, Pacific Forestry Centre, 5606 W Burnside Rd, Victoria BC V8Z 1M5, Canada

V. Alexeyev

Russian Acad Sci, Vn Sukachev Inst Forests Res, Novosibirsk, Russia

J. Fang

Coll Environm Sci, Department Ecol, Peking University, Beijing 100871, People's Republic of China

J.-P. Gattuso

Observatoire Océanologique, Laboratoire d'Océanographie, CNRS-UPMC,

B. P. 28F-06234 Villefranche-sur-mer Cedex, France

J. P. Guerschman

CSIRO Land and Water, GPO BOX 1666, Canberra 2601, Australia

Y. Huang

Inst Atmospher Phys, Chinese Acad Sci, Beijing 100029, People's Republic of China

E. Jobbagy

Grupo de Estudios Ambientales, Universidad Nacional del San Luis \& CONICET,

Ej de los Andes 950, San Luis 5700, Argentina

D. Murdiyarso

CIFOR, POB 6596 JKPWB, Jakarta 10065, Indonesia

J. Ni

Chinese Acad Sci, Inst Bot, Lab Quantitat Vegetat Ecol,

Xiangshan Nanxincun 20, Beijing 100093, People's Republic of China

A. Nobre

Inst Nacl Pesquisas da Amazônia, Escritório Regional no INPE,

Sigma, Av. dos Astronautas 1758, Sao Jose dos Campos SP 12227-010, Brazil

C. Peng

Institute of Environment Sciences, University of Quebec at Montreal Case postale 8888, succ Centre-Ville, Montreal, QC H3C 3P8, Canada

A. Walcroft

Landcare Research, Private Bag 11052, Palmerston North, New Zealand

S. Q. Wang

Chinese Acad Sci, Inst Geog Sci and Nat Resources Res,

Beijing 100101, People's Republic of China

Y. Pan

USDA Forest Service, Global Change Program,

11 Campus Blvd, Ste. 200, Newtown Square, PA 19073, USA

G. S. Zhou

Inst Bot, Lab Quantitat Vegetat Ecol, Chinese Acad Sci,

Beijing 100093, People's Republic of China

Present address:

J. Ni

Max Planck Institute for Biogeochemistry, Hans-Knoell-Strasse 10,

P.O. Box 100164, 07701 Jena, Germany 
the global carbon cycle include human utilization of fossil fuels and impacts on less intensively managed systems such as peatlands, wetlands and permafrost. A great deal of knowledge, expertise and data is available within each sector. We describe the contribution of sectoral carbon budgets to our understanding of the global carbon cycle. Whilst many sectors exhibit similarities for carbon budgeting, some key differences arise due to differences in goods and services provided, ecology, management practices used, landmanagement personnel responsible, policies affecting land management, data types and availability, and the drivers of change. We review the methods and data sources available for assessing sectoral carbon budgets, and describe some of key data limitations and uncertainties for each sector in different regions of the world. We identify the main gaps in our knowledge/data, show that coverage is better for the developed world for most sectors, and suggest how sectoral carbon budgets could be improved in the future. Research priorities include the development of shared protocols through site networks, a move to full carbon accounting within sectors, and the assessment of full greenhouse gas budgets.

\section{Introduction}

Humans have a great influence on the global carbon (C) cycle and utilise about $40 \%$ of the earth's net primary production (NPP; Vitousek et al. 1986; Rojstaczer et al. 2001). The utilisation of this NPP is often distributed among different sectors, with, for example, timber and forest products within the forestry sector and food and fibre products from croplands and grasslands within the agricultural sector. Anthropogenic impacts on the global $\mathrm{C}$ cycle also include human utilization of fossil fuels and human impacts on less intensively managed ecosystems such as peatlands, wetlands and areas of permafrost. A great deal of knowledge, expertise and data is available within each of these sectors. This knowledge, expertise, and data can be utilised to produce regional and global $\mathrm{C}$ budgets for each sector, and these in turn complement full, cross-sectoral, regional $\mathrm{C}$ budgets, in which each sector is often treated more simply.

In addition to providing more detailed and specific expertise to describe regional $\mathrm{C}$ budgets, studies of the individual sectors and the interactions between sectors (such as the use of biomass for energy to substitute for fossil fuels in energy production) give us insight into the processes and changes in regional $\mathrm{C}$ budgets. Sectoral budgets, along with regional budgets, also help to communicate $\mathrm{C}$ budgets and management options to those who manage land or energy systems, or are otherwise stakeholders in a world of changing $\mathrm{C}$ budgets. A multi-sectoral, regional $\mathrm{C}$ budget might seem rather abstract to a land manager such as a forest manager or farmer; but sectoral and regional $\mathrm{C}$ budgets expressed in terms of timber, wood, food, or fibre management will be more accessible. It is thus easier for stakeholders to see the opportunities and consequences of management decisions they take if the $\mathrm{C}$ budget is expressed in products or units with which they are familiar. Decisions that influence the $\mathrm{C}$ budget can be taken by these stakeholders in an environment of understanding and appreciation. In terms of climate change mitigation, it is very specific management practices in agriculture, forestry and nature conservation that are required. By assessing the $\mathrm{C}$ budget by sector and by region, and by expressing mitigation options in terms of sector and region-specific management options, implementation and consequences should be clearer to both resource managers and policy makers. This will also make the implementation and consequences of the Kyoto Protocol clearer to both resource managers and policy makers. 
In this review we include the forest sector, the agricultural sector, peatlands/wetlands/ permafrost areas (since these are significant land uses in the global $\mathrm{C}$ cycle) and the fossil fuel/other anthropogenic sector. The latter is the only non-land-based sector, but it is included since it is a key driver of evolving changes in the $\mathrm{C}$ cycle, and it interacts closely with the other sectors covered here. Whilst most terrestrial components of the $\mathrm{C}$ cycle fall fairly logically into one of these categories (sectors), there are of course overlaps, for example the use of forest and agricultural products as biofuels, or the use of fossil fuels in agriculture and forestry. The interactions and feedbacks between sectors are discussed in section 7. This paper does not deal with other components of the terrestrial $\mathrm{C}$ budget or the oceans or atmosphere. The forest sector is here defined as the land use where trees are the dominant vegetation type for most of the time. It excludes agro- forestry types of systems and excludes the short rotation ( $<10$ year) bioenergy systems which are included in the agriculture sector. The sector is producing timber, wood products and other forestry products (e.g. fuel). It is linked with other land-based sectors such as the croplands and grasslands through competition for land. The agricultural sector is defined as the sector producing food, fibre and other agricultural products (e.g. fuel) from cultivated lands and grasslands. Apart from their productive capacity, both the Forestry and Agricultural sectors provide a number of other ecosystem services such as climate regulation, air and water purification, nutrient and waste cycling and soil stabilization. Peatlands/wetlands/permafrost areas considered here are usually unmanaged, or only extensively managed, and are included due to the large and vulnerable stock of $\mathrm{C}$ they contain. The fossil fuel sector includes fossil fuel energy use and $\mathrm{C}$ emissions from all human activity and is included as it is a key driver of changes in the global $\mathrm{C}$ cycle.

\section{Key similarities and differences between sectors}

Many of the sectors can be described similarly in terms of stocks (pools), flows, processes and turnover rates. Figure 1 shows a schematic representation of the $\mathrm{C}$ cycle in a grassland, but the pools and flows are similar for all land-based sectors. Table 1 provides order of magnitude estimates of the dimensions of the pools, fluxes, and turnover times for each sector as shown in Fig. 1.

Despite some similarities, there are also a number of differences between sectors, the main one being the difference between the fossil fuel/other anthropogenic sector and the land-based sectors. The fossil-fuel sector is the only sector that is characterized by $\mathrm{C}$ flows that are in one direction only, on the time scale of human interest.

Though the land-based sectors show many similarities there are a number of significant differences, as described below.

Goods and services provided Forests and agricultural lands provide very different products and services, including many commercially valued products and services, though some services can be complementary (e.g. leisure and amenity use of land). Peatlands/wetlands/ areas of permafrost, on the other hand, whilst they may provide some commercially valued services such as fuel and garden products from peat, mainly provide non-market services such as wildlife, biodiversity conservation, recreation, watershed protection.

Ecology The land-based sectors also have very different ecologies, with very different flora, fauna and biodiversity represented in each. For example annual crops complete their life cycle in 1year, whereas trees which can continue to grow for many decades/centuries. There are also, of course, a great variety of ecologies for each land-use type (e.g. tropical vs 
$\mathrm{kg} \mathrm{C} \mathrm{m-2} \mathrm{yr-1}$

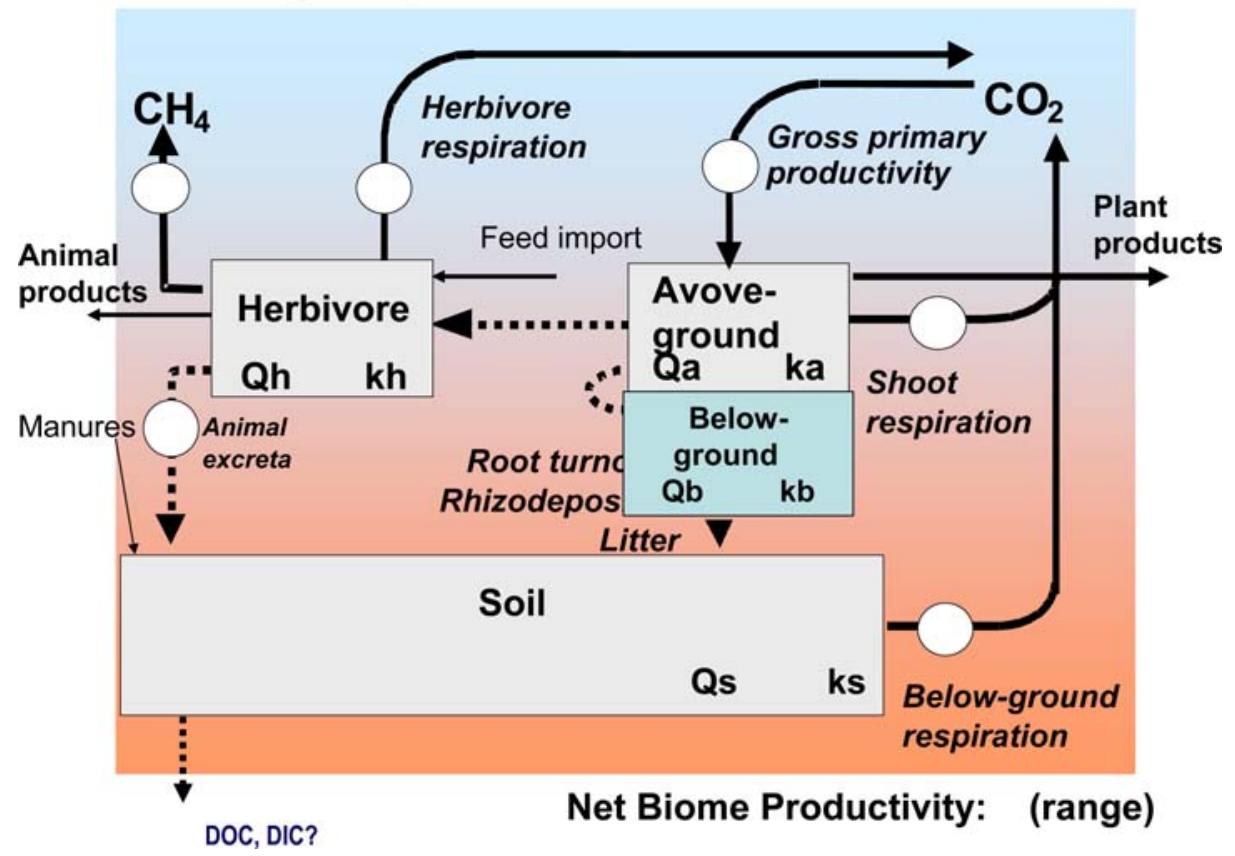

Fig. 1 Schematic diagram of pools, processes, turnover rates for land-based sectors. Pool sizes and turnover rates for each sector are given in Table 1

boreal forests) and each sector presents a multitude of challenges for measurement and interpretation. The challenges of measurement and interpretation are dealt with in more detail in Section 3 below.

Management practices used Management activities that affect the $\mathrm{C}$ cycle are very different among sectors. Management in croplands and grasslands (e.g. tillage, fertilisation, organic amendments, drainage, irrigation, rotation, livestock management) is intensive and occurs almost continuously; whereas management in forests might be intensive at first (drainage, cultivation, planting) with periods of less intensive management (fertilization, thinning) later. Peatlands/wetlands/areas of permafrost are usually less intensively managed, with protection and restoration, or drainage and degradation, the dominating management impacts. The different management intensities and techniques for management make the impact of management on the $\mathrm{C}$ cycle very different among sectors.

Land-management responsibility The sectors are managed by different people. Agricultural lands are managed by farmers, forests by foresters and peatlands/wetlands/areas of permafrost often by conservation bodies (unless under another sector, e.g. peatlands under forestry). Each set of land managers has a different background, perceptions and suite of accepted practices. The management of the land is often shaped by prior knowledge and influenced by many factors including education and public policy.

Policies affecting land management Policy is often formulated differently within different sectors. Agriculture, forestry and wetland management often are not the responsibility of 


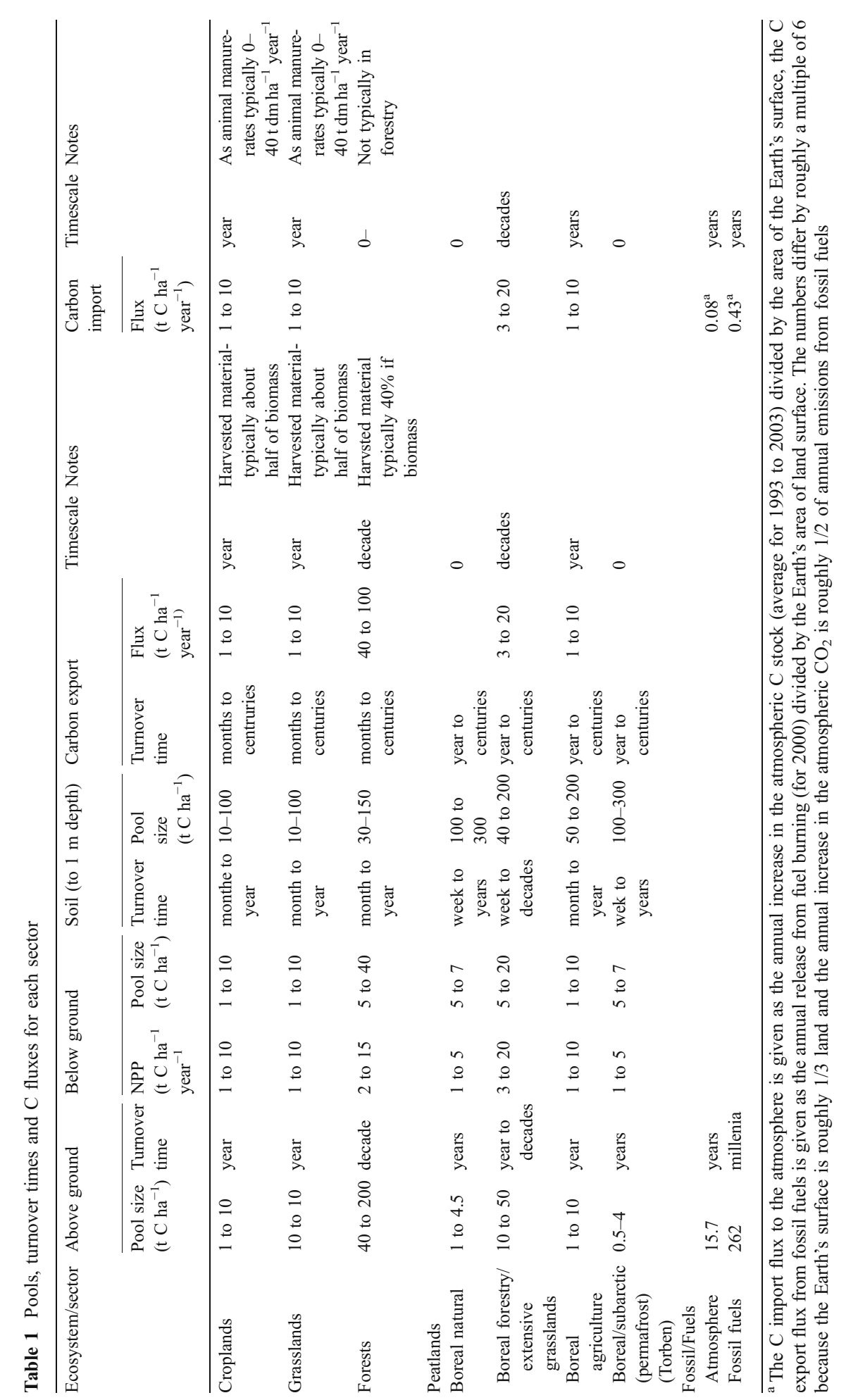


the same policy makers. Different policies are often driven by the different needs of each sector and reflect the difference in the products and services they provide, ecology, and management as described above.

Data types and availability Data sources are often very different for different sectors, again often driven by the different goods and services provided. In many regions of the developed world there are comprehensive forest inventories, collected to assess timber volume, but invaluable for $\mathrm{C}$ budgeting. Agricultural statistics have often been collected in developed countries for the purposes of assessing agricultural markets and for yield improvement but, again, these prove extremely useful for $\mathrm{C}$ budgeting. Sectors with less obvious commercial goods, such as wetlands and areas of permafrost, encourage less data collection, except for scientific study. Emissions of $\mathrm{CO}_{2}$ from fossil-fuel combustion can be estimated with considerable accuracy because fossil-fuel combustion is an activity of major economic importance and because $\mathrm{CO}_{2}$ is the equilibrium product of combustion. There are data on production, trade, and consumption that can be compiled from virtually the initiation of the industrial era. However, most fuel data are available at the spatial scale of large political entities (such as countries) and at the temporal scale of years, so estimates at smaller spatial and temporal scales generally depend on models or proxy data.

Drivers of change Whilst many sectors share similar indirect drivers such as climate change, nitrogen deposition, pollution, pressure on land for other uses; there are also a number of drivers that are specific to each sector. Timber and wood-product markets are very different from markets for agricultural products or fossil fuels, and these produce very different driving forces. Further, the markets are affected differently by different forces; agriculture and forestry might be affected greatly by drought, but fossil fuels are likely to be less affected. Conversely, war in the Middle East may have a profound effect on oil markets but may directly affect food, fibre and wood products very little.

\section{Tools used to study sectoral carbon budgets}

There are a number of common tools that can be used to help assemble sectoral $\mathrm{C}$ budgets. Many tools such as $\mathrm{C}$ isotope studies, eddy covariance methods to measure $\mathrm{C}$ fluxes, chamber flux measurements of $\mathrm{C}$ and other greenhouse gases, inventories of above- and below-ground biomass, book-keeping modelling, process modelling, experimental manipulation and earth observation (e.g. remote sensing) play a role in assessing the $\mathrm{C}$ budget of all land-based sectors. These are described in more detail below.

\subsection{Eddy covariance networks}

The eddy covariance technique attempts to directly measure net exchange at the ecosystem/ atmosphere interface, recording the fluxes of carbon dioxide $\left(\mathrm{CO}_{2}\right)$ flowing in to and out of the ecosystem several times per second. The integration of a succession of instantaneous eddy flux measurements over longer periods, typically comprising the full physiological daily or seasonal cycles, will produce the net ecosystem exchange (NEE), a parameter which in theory accounts for both autotrophic and heterotrophic $\mathrm{CO}_{2}$ exchanges with the atmosphere (Fig. 2). Because plants exchange most of their carbon as $\mathrm{CO}_{2}$, eddy flux 


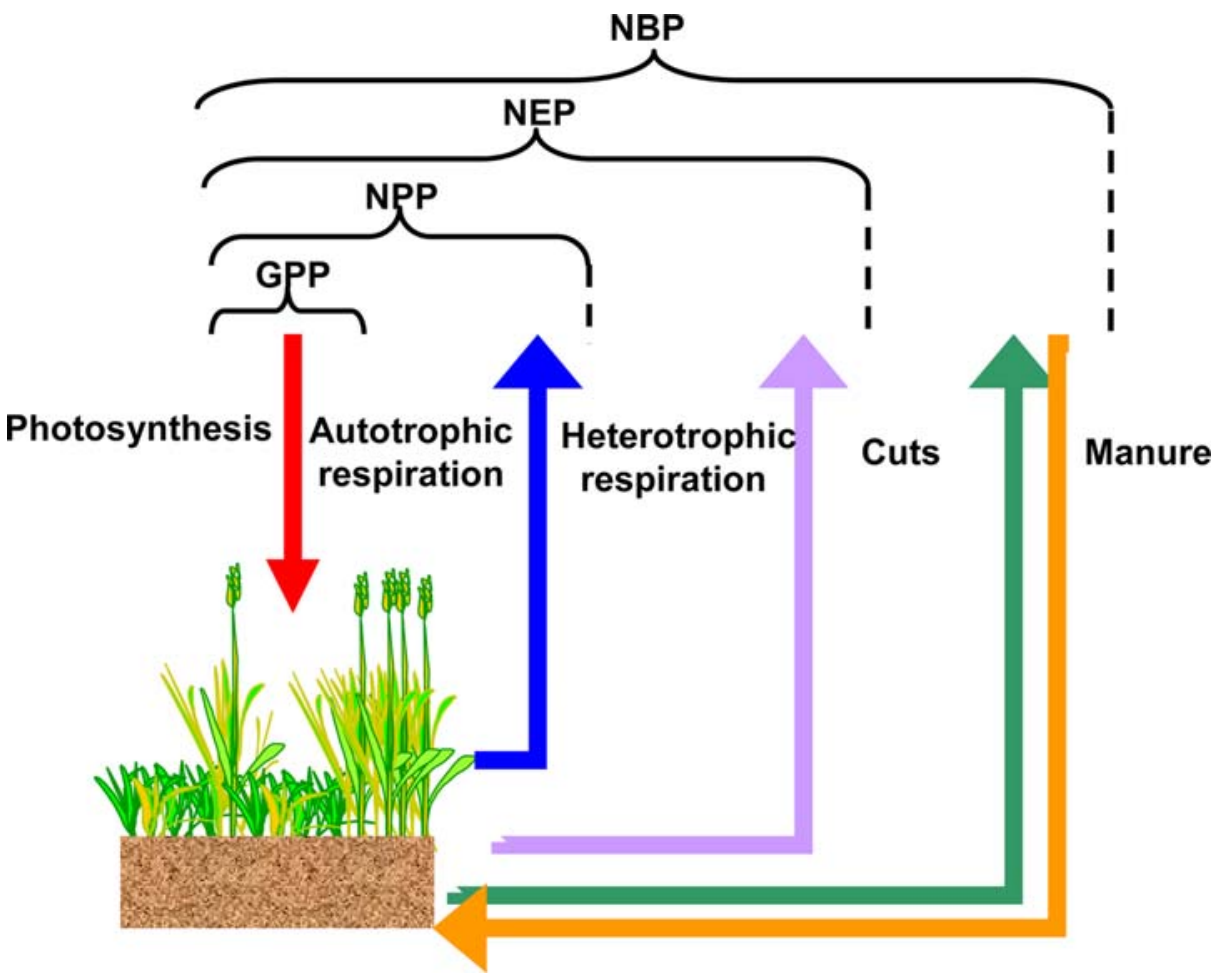

Fig. 2 Components of the Net Biome Productivity in a managed grassland. Fire is another form of disturbance in fire prone grasslands

derived NEE is an ideal parameter for $\mathrm{C}$ budgeting from local to regional scales. Over time, net $\mathrm{C}$ fluxes are good proxies for ecosystem total biomass stock change (Baldocchi 2003). There are hundreds of eddy flux towers monitoring continuously and organized in a global network (www.fluxnet.org). Most of the early eddy-covariance flux towers were used for forest ecosystems (Valentini et al. 2000) the network now covers most land uses (Baldocchi 2003). In Europe, for example, the proportion of cropland and grassland sites in the flux tower network roughly matches the proportion of the land surface covered by croplands and grasslands (CarboEurope-IP 2004).

Main problems with the technique are the requirement for turbulence and lateral drainage of $\mathrm{CO}_{2}$. Some turbulence, produced by the interaction of wind with canopies, is required; the stronger the wind the smaller the measurement footprint. In forests for instance, an eddy flux tower with 20 m clearance to the canopy top will typically have a measurement footprint reduced to a few hundred meters in windy conditions, and increased to several kilometres in gentler winds. During the night-time forests with dense and closed canopies can accumulate $\mathrm{CO}_{2}$ (Baldocchi 2003). Since it is rare for a flux tower to be sited on completely flat terrain, even gentle topography can lead to lateral drainage of accumulated $\mathrm{CO}_{2}$, which produces a displacement that can result in an artificially large net sink $\left(\mathrm{CO}_{2}\right.$ absorbed by photosynthesis is well measured during the day; $\mathrm{CO}_{2}$ released by respiration during the night is not totally accounted for in the fixed measurement location). These shortcomings present significant challenges but some recent studies promise to, at least partly, address these shortcomings (Kruijt et al. 2004), and eddy flux 
gap filled data can match stock change measurements satisfactorily (Saleska et al. 2003). Process-based models benefit greatly from validation with eddy flux data (Morales et al. 2005). Variants of the eddy flux technique can be used for measurements of other $\mathrm{C}$ gases like $\mathrm{CH}_{4}$ and volatile organic compounds, allowing for a quasi complete closure of gaseous $\mathrm{C}$ balances between a monitored forest stand and the atmosphere (Ciccioli et al. 1999; Kesselmeir et al. 2002). For a complete closure of the $\mathrm{C}$ balance, also the $\mathrm{C}$ losses via wood export and via DOC/POC leaching should be accounted for.

Eddy covariance techniques encounter a number of problems when used in agriculture, particularly when used on croplands. Firstly, forest towers often cover areas that are not as intensively managed as croplands and intensive grasslands. This means that disturbance can be an issue on agricultural sites. Secondly, since nearly all crops are sown and harvested annually, and are often grown in rotation, the impact of previous crop or management in the previous year can have a far greater effect in croplands than in perennial grasslands or forest ecosystems. The impact of recent management history is therefore far more important for cropland sites. The most important issue, however, relates to the diversity of croplands and how representative the cropland flux towers can be. In forest systems, towers can be placed in similar age stands of similar species in a number of regions. This ensures some degree of homogeneity that allow sites to be compared (Morales et al. 2005) and even for results to be directly up-scaled (Papale and Valentini 2003). For croplands, however, the range of crops, tillage practices, crop management practices and recent land-use/land management histories is so large that no two sites are likely to be comparable, i.e. even if they have comparable crops, they are likely to use different tillage regimes, fertilization practices and to occur as part of a different rotation. The cropland landscape is also more heterogeneous over small spatial scales, with individual fields often growing different crops. This diversity makes direct comparison between sites or direct up-scaling virtually impossible. Instead, processbased models are necessary to interpret the contributions to the measured net ecosystem exchange (NEE) at each site. Eddy covariance techniques encounter some specific problems when used in grasslands and rangelands. In some intensively managed areas (e.g. in Europe) grassland landscapes include a large number of paddocks that are managed differently by grazing and cutting. The area within the footprint of the $\mathrm{CO}_{2}$ masts should not exceed the size of a paddock (usually a few hectares or less), so that it is necessary to reduce the fetch of the sensors, and hence the height of the masts, leading to loss of part of the eddy spectrum (Soussana et al. 2004). In contrast, the low grazing intensity and large paddock size usually found in rangelands and extensive grasslands, makes it possible to use taller masts. There is also a possibility that the respiration by large grazing herbivores is not fully taken into account by the eddy covariance calculations, since herbivores are point sources of emissions. However, comparisons with and without cattle show a larger ecosystem respiration rate when cattle is included (A. Hensen, personal communication). It would seem, therefore, that as long as the herbivores are within the footprint of the sensors, the animal respiratory $\mathrm{CO}_{2}$ will be rapidly diluted in the background air and transported by turbulence to the sensors. Nevertheless, animals that come too close to the sensors lead to $\mathrm{CO}_{2}$ spikes that are likely to be rejected when filtering the data. NEE accounts for the $\mathrm{CO}_{2}$ exchange between the ecosystem and the atmosphere as measured by the masts. Therefore in grazed only pastures, where all the herbage biomass is recycled on site through ruminant respiration, and where no organic fertilizers are applied, NEE approximates the $\mathrm{C}$ balance of the grassland, i.e. the Net Biome Productivity (NBP, Fig. 2). By contrast, in most instances organic $\mathrm{C}$ is either exported from the grassland plots by cuts or is imported through the application of manures. In this case, the net biome productivity (NBP) of the grassland (which accounts for net changes in ecosystem $\mathrm{C}$ stocks) can be calculated as the 
NEE, plus organic $\mathrm{C}$ imports from manure applications, minus organic $\mathrm{C}$ exports in the cut dry-matter (Fig. 2). This allows us to compare cut and grazed sites, those supplied or not with manure, on a common basis which reflects the net storage of $\mathrm{C}$ in a grassland plot. Main uncertainties in eddy covariance data arise from uncertain footprint, disturbance within the footprint, gap filled data and $\mathrm{CO}_{2}$ storage or flow outside the footprint during the night-time. These uncertainties have been discussed previously (e.g. Baldocchi 2003).

\subsection{Measuring changes in carbon in plants (inventory)}

Inventory-based $\mathrm{C}$ budgets have predominantly been used in the forest sector. Here they are used to quantify the net forest sector $\mathrm{C}$ sink in one of two ways: from repeated plot-level surveys, or from one larger scale survey in combination with empirical age-class yield models. Repeat surveys and permanent plots are more common in commercially productive temperate forests, while age-class models are used more often in boreal regions, where there are few economic incentives for establishing a network of permanent plots, and where the logistical challenges are substantial. Repeat surveys of millions of trees automatically reflect the integrated, net effect of all factors influencing tree growth, from losses caused by harvests or natural disturbances, to gains from improved forest management, fire suppression, or altered environmental conditions (e.g. longer growing seasons or elevated atmospheric $\mathrm{CO}_{2}$ or $\mathrm{N}$ deposition). Age-class yield models use empirical forestry yield tables or biomass curves to predict expected growth at each age class. Age-class distribution, harvests, and natural disturbances then need to be tracked through time.

Inventory-based $\mathrm{C}$ budgets in the forest sector have been used to estimate forest $\mathrm{C}$ uptake in Canada (Kurz and Apps 1999), and Russia (Isaev et al. 1995; Alexeyev et al. 1995; Shvidenko et al. 1995). Estimates of forest C uptake from this approach do not include any changes in tree growth rate that might occur after model construction (i.e., from altered environmental conditions), and are sensitive to accurate quantification of the area and severity of disturbances.

In the agricultural sector, yields are routinely measured but this accounts only for the harvested product and does not equate to total plant dry matter. Because of continuous disturbance, above-ground stocks vary quickly. Moreover, in grasslands there is large spatial heterogeneity due to grazing and plant species diversity. Agricultural management tends to be poorly documented in agricultural statistics. In grazed systems, there are no records of yields, and animal production cannot be directly related to herbage production.

Animal production is often difficult to estimate (numbers known, but not always liveweights). While $\mathrm{C}$ is predominantly stored below-ground in grasslands and rangelands, above-ground $\mathrm{C}$ stocks should not be neglected. Above-ground $\mathrm{C}$ stocks may vary widely among grassland and rangeland types. For example, in China, the ratio of above to belowground C stocks varied from ca. 0.2-1.2 in different steppes and deserts (Ni 2002, 2004a, b).

Moreover, grassland and rangeland ecosystems combine high plant diversity with rapid dynamics, as a result of frequent disturbance by grazing, browsing and mowing. This has several implications for the assessment of $\mathrm{C}$ stocks. First, the above and below ground plant mass displays large seasonal variations which are strongly affected by the management, e.g. by defoliation which also affects the root dynamics. Second, the spatial heterogeneity of the vegetation tends to increase with grazing, as a result of interactions with herbivores (Garcia and Holmes 2005). Third, differences in plant functional types may also lead to large differences in above and below-ground C stocks, even at a short distance within the same plot. Stratified sampling according to vegetation type and vegetation structure may therefore increase the accuracy of $\mathrm{C}$ stock estimates. Whilst inventories can be used in combination with gas flux 
measurements to assess the ecosystem $\mathrm{C}$ balance, only gas flux measurements can be used to assess non- $\mathrm{CO}_{2}$ fluxes. Main uncertainties arise in plant $\mathrm{C}$ inventories from the allometric relationships, yield tables and biomass expansion factors used to convert single measurements (such as diameter at breast height) to volume, biomass and $\mathrm{C}$ content.

\subsection{Measuring changes in carbon in the soil}

For soil $\mathrm{C}$, long term $\mathrm{C}$ cycling is often studied by measuring changes in total soil organic carbon (SOC) over long periods (years to decades; Smith et al. 1997a). In many sites, while soil organic matter concentration has been measured over many years, calculations of total soil organic $\mathrm{C}$ contents has long been hindered by a lack of data concerning soil bulk density and by discrepancies in sampling techniques (e.g. no standardisation of soil depth and of soil layers). In the last decade, individual long-term experiments have been brought together into networks such as the Soil Organic Matter Network (SOMNET; Smith et al. 2001a) and EuroSOMNET (Smith et al. 2002a, b). Such networks allow the impacts of management practices on SOC stocks to be determined and for regional projections of the impact of different management strategies to be explored (e.g. Smith et al. 1997b, 1998, 2000, 2007a; Freibauer et al. 2004; Ogle et al. 2005). Most methods concerning soil surveys and soil measurements have been developed in similar ways both for arable and for grassland soils. However, there are some specific problems for measuring $\mathrm{C}$ stocks in grassland soils. Soil C stocks display a high spatial variability (coefficient of variation of $50 \%$, Cannell et al. 1999) in grassland as compared to arable land and ca. 15\% of this variability comes from sampling to different depths (Robles and Burke 1998; Chevallier et al. 2000; Bird et al. 2002). In addition to measurement of changes in bulk SOC, other techniques are now being used to better understand SOC turnover. Various fractionation techniques are being used to isolate different fractions of SOC (e.g. Six et al. 2001; Del Galdo et al. 2003) to better understand SOC turnover, and to identify sensitive indicators of SOC change. Mathematical methods to test the match between measured fractions and model pools are being developed (e.g. Smith et al. 2002a, b), to allow the understanding from these fractionations to be incorporated into process-based models. The $\delta^{13} \mathrm{C}$ natural abundance tracer technique utilises the fact that plants with a $\mathrm{C} 3$ photosynthetic pathway have a different $\delta^{13} \mathrm{C}$ isotopic signature compared to plants with a $\mathrm{C} 4$ photosynthetic pathway. When $\mathrm{C} 3$ plants have been replaced by $\mathrm{C} 4$ plants, or vice versa, the $\delta^{13} \mathrm{C}$ changes and allows new $\mathrm{C}$ inputs to be separated from old $\mathrm{C}$. The technique has been in use for some time (Balesdent et al. 1987; de Moraes et al. 1996) but is still yielding important new results, especially when coupled with modelling techniques. The ${ }^{13} \mathrm{CO}_{2}$ pulse labelling technique also shows promise for improving our understanding of SOC turnover. This technique uses the stable ${ }^{13} \mathrm{C}$ isotope, pulsed as ${ }^{13} \mathrm{CO}_{2}$ for 1 or 3 days from a chamber enclosing the plants. The ${ }^{13} \mathrm{C}$ isotope signal is then tracked in shoots, roots, and rhizosphere soil during the months following the pulse. In grassland sites, very rapid turnover of $\mathrm{C}$ has been observed (Rangel-Castro et al. 2004). ${ }^{14} \mathrm{C}$ bomb $\mathrm{C}$ can also be extremely useful in examining soil $\mathrm{C}$ turnover, especially when coupled with models (Jenkinson and Coleman 1994; Hahn and Buchmann 2004).

In peat forming wetlands the determination of the $\mathrm{C}$ balance may come from two different methods; current exchange measurements, and estimates of rates of long-term $\mathrm{C}$ storage from analysis of the peat profile. Atmospheric flux monitoring using chambers and/ or eddy covariance are commonly applied but to date are usually limited to $\mathrm{CO}_{2}$ balances, with only few studies taking into account $\mathrm{CH} 4$, VOC, and DOC/POC balances. The longterm organic carbon accumulation rates (LORCA) are often studied to relate variations in $\mathrm{C}$ 
sequestration with proxies of variations in climate (Gorham 1991; Lappalainen 1996). The LORCA is sometimes difficult to reconcile with current exchanges using standard flux measurement techniques. This may in part be due to the current flux measurements rarely taking into account the losses of $\mathrm{CH}_{4}-\mathrm{C}$ and also the loss through DOC export in streamwater (Malmer et al. 2005). The estimates of LORCA on their part are based on analyses of peat profiles and critical parameters measured are depth/bulk density profile and organic C content (Turunen et al. 2001). These are often not available to any desirable extent. Main uncertainties in soil inventories arise from spatial heterogeneity, sampling depth and poorly known secondary measures, such as bulk density.

\subsection{Models, databases and remote sensing}

The main method for interpreting flux (and other) results, and for extrapolating temporally and spatially, is the use of process-based models. Process-based models are continually being improved, with the most significant advance in the last decade being the development, and testing of models that simulate all biogenic greenhouse gases. The main hurdle to applying such models at the regional level is data limitation. In recent years, highresolution, spatially explicit datasets have become more readily available. National, regional and global databases have been improved and it is now possible to run models for entire sub-continental regions (e.g. EU-25, USA) at fine spatial scale such as a $10^{\prime}$ by $10^{\prime}$ grid (Rounsevell et al. 2005; Mitchell et al. 2004; Smith et al. 2005) or at US county level (Parton et al. 2005). Historical climate data have been interpolated to higher spatial resolution and future climate scenarios from global climate models have been downscaled to the same spatial resolution (e.g. Mitchell et al. 2004). Soil data is now available at high spatial resolution (e.g. at $1 \mathrm{~km}^{2}$ for Europe; Jones et al. 2003, 2004) and historical land-use data and future land use scenarios are beginning to be constructed at high resolution (e.g. Rounsevell et al. 2005). There are many areas in which these datasets require further improvement, but significant advances have been made in some regions in recent years. In some regions, however, especially in the developing world, such datasets are poor or non-existent.

Improvements in remote sensing capability and products have greatly improved datasets on land use and land cover and enabled improvements in modelling the consequences of recent land-use change. All land based sectors use process based models and remote sensing products. Below, we illustrate the use of models and remote sensing with examples from the forest sector.

Process modelling In the forest sector, numerous models exist at a variety of levels of complexity operating at variety of spatial (leaf, canopy, stand, biome) and temporal (seconds, days, years, centuries) scales. Improvements in both computing power and theoretical understanding of canopy processes (de Pury and Farquhar 1997; Chen et al. 1999) have allowed the inclusion of greater mechanistic complexity in large-scale, longterm simulation models (e.g. InTEC, Chen et al. 2000). Another recent advance is the explicit linkage of above- and below-ground processes, enabling simulation of both $\mathrm{C}$ and nutrient (particularly nitrogen) fluxes within and between vegetation and soil pools (e.g. PnET-CN, Aber and Driscoll 1997; TEM, McGuire et al. 1997).

Process-based models must be tested and validated using the results from the other methods in the forest sector, such as site-based eddy covariance or forest inventory measurements (Aber and Driscoll 1997; Running et al. 2004). Such models can be used 
diagnostically to interpret temporal and spatial patterns of forest $\mathrm{C}$ stocks and fluxes (e.g. Zhou et al. 2002), and attribute causation to various climatic drivers and different environmental stressors such as $\mathrm{CO}_{2}$ fertilization, $\mathrm{N}$ deposition and tropospheric ozone (Ollinger et al. 2002; Felzer et al. 2004; Pan et al. 2004). Mechanistic models may also be used for prognosis, to predict forest ecosystem responses to future climate scenarios (Medlyn et al. 2000), and to provide feedback to coupled climate-C cycle models.

Validated models can be used at either site or regional levels as needed, given appropriate spatial input data. National, regional and global databases are generally available today, but in different quality and resolution. For example, high-resolution $\left(1 \mathrm{~km}^{2}\right) \mathrm{N}$ deposition and ozone data are available for the continental US (Sheeder et al. 2002; Pan et al. 2008). Historical climatic data are available at different spatial resolutions: data at $0.5^{\circ}$ are available for globe (Mitchell et al. 2004); finer resolution data at $1 \mathrm{~km}^{2}$ are available for the US and China (Thornton et al. 1997 and www.daymet.org; Fang et al. 2003). In the future, high resolution databases for different regions will be a critical when applying process-based models in regional forest sector $\mathrm{C}$ budgets.

Process models of $\mathrm{C}$ accumulation in peatlands attracted early interest in a possible theoretical limit for peat growth under natural conditions (Clymo 1984). Further refined peat accumulation models have been developed (e.g. Frolking et al. 2001) and recently a framework for modelling peatlands as more complex spatially heterogenuous systems was proposed (Belyea and Baird 2006). In addition to the issue of $\mathrm{C}$ balance alone important features of peatland ecosystem functioning such as $\mathrm{CH}_{4}$ emissions has been subject to several modelling approaches (e.g. Cao et al. 1996; Christensen et al. 1996; Walter et al. 2001). Recently simple schemes have been applied for translating remote sensing information on ecosystem $\mathrm{C}$ cycling into large scale wetland $\mathrm{CH}_{4}$ emission estimates for individual nations (Potter et al. 2006).

Hybrid models Basic approaches to modelling forest $\mathrm{C}$ budget and dynamics include empirical, process-based, and hybrid forest $\mathrm{C}$ budget models, each with their advantages and limitations (Landsberg 1986; Kauppi et al. 1992; Turner et al. 1995; Schroeder and Winjum 1995; Kurz and Apps 1999; Kimmins et al. 1999; Peng 2000; Fang et al. 2001; Liu et al. 2002). Empirical models are limited in their applicability to situations outside those for which they were constructed, and process models are often hampered by more demanding larger data requirements. However, empirical and process models can be married into hybrid models in which the shortcomings of both approaches can, to some extent, be overcome. This is the rationale behind the hybrid simulation approach to forest growth and C dynamics modelling (Battaglia and Sands 1998; Kimmins et al. 1999; Peng 2000) that can predict forest growth, production and $\mathrm{C}$ budgets in both the short and long term (Pastor and Post 1988, Battaglia and Sands 1998; Kimmins et al. 1999). For example, TRIPLEX1.0 (Peng et al. 2002) is a hybrid, monthly time-step model of forest growth and $\mathrm{C}$ dynamics. TRIPLEX integrates the forest production model of 3-PG (Landsberg and Waring 1997), the forest growth and yield model of TREENYD3.0 (Bossel 1996), and the soil-carbon-nitrogen model of CENTURY4.0 (Parton et al. 1993). The model is intended to minimize the number of input parameters required, while capturing key processes and important interactions between the carbon and nitrogen cycles of forest ecosystems. TRIPLEX1.0 has been successfully used to simulate the forest $\mathrm{C}$ budget of Abitibi Model Forest from 1990 to 2000 in Ontario, Canada (Zhou et al. 2008). Hybrid approaches may be useful in bridging the gap between empirical forest $\mathrm{C}$ accounting and process-based $\mathrm{C}$ balance models. 
Remote sensing Extensive accounting of pools and fluxes for full $\mathrm{C}$ accounting (FCA) using direct field measurements would be prohibitively laborious and expensive (e.g. Gluck et al. 2000). A diverse array of airborne and space-borne sensors are capable of providing image data that can aid in $\mathrm{C}$ accounting for forests and derived land uses (Fig. 3).

Remote sensing data and land information systems for $\mathrm{C}$ accounting have been particularly successful when land is converted from forest to other land use (Nobre and Harriss 2002; Fig. 4). The availability of at least 30years of frequent Landsat coverage for all the continents also allows historical land use change to be reconstructed. In the 1990s new satellites bearing active sensors like Radarsat and JERS generated extensive maps of vegetation densities, but the SAR signal saturated with biomass densities larger than $70 \mathrm{t} \mathrm{ha}^{-1}$, rendering these data inappropriate for studying important mass variations in natural and managed forests. However, JERS data could reveal flooded vegetation hidden by dense canopies, and has been used to map wetlands, especially in the tropics.

Remote sensing and terrain modelling also offer great advances in mapping of environments for $\mathrm{C}$ cycle assessment. The Shuttle Radar Topographic Mission (SRTM, NASA) of 2000 produced the finest terrain model to date. Even though the SRTM did not penetrate forest canopies, its digital elevation model has been used to partition of forest types according with their position (Williams et al. 2002). Forest type maps derived from remote sensing and spatial modelling can serve the forestry stand-level community in simplifying their sampling efforts. Conversely, these maps can be joined with stand-level C inventory calibration data to generate relevant area budget extrapolations.

Future developments include the use of instruments that are currently airborne on satellites or the space shuttle and new-generation $\mathrm{CO}_{2}$ sensors. For example, LVIS and

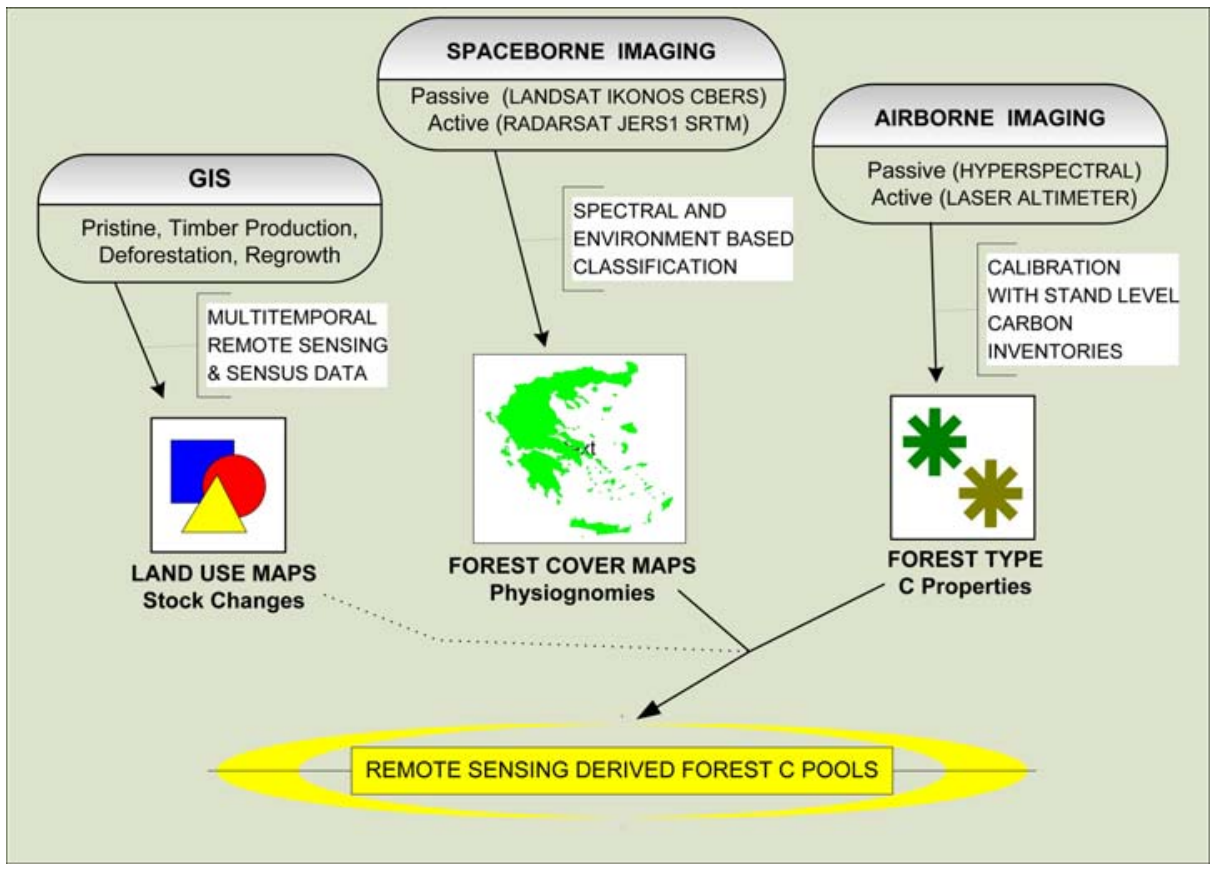

Fig. 3 Expansion of scale in budgeting $\mathrm{C}$ for forests using remote sensing and geographical information system data, calibrated with stand level inventories and census data 

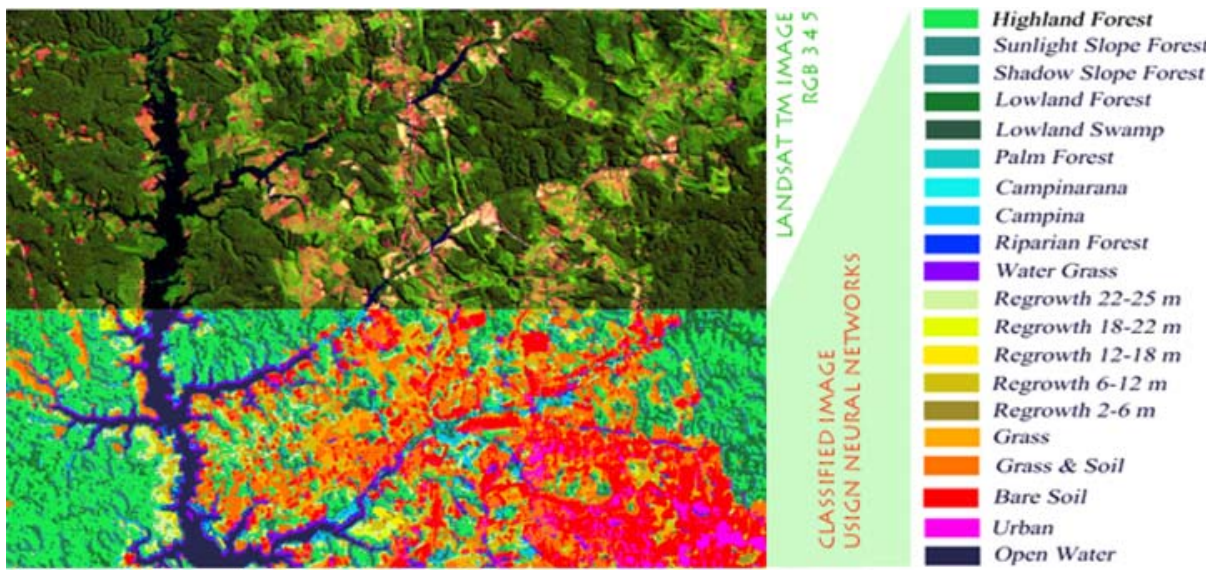

Fig. 4 Landsat TM image of a forest area in Amazonia Brazil (top half), under pressure of land use change, and classified portion (lower half) giving extent of land use classes that can be associated with $\mathrm{C}$ stocks and dynamics (Nobre and Harriss 2002)

related airborne active sensors (Fig. 5) are not yet space-borne but the latest version of the LVIS instrument allows it to be used with standard aerial photographic windows, meaning that it might soon be feasible to operate full $\mathrm{C}$ accounting for forests using such technology. Such instruments will eventually be mounted on the space shuttle or satellites. A new generation of $\mathrm{CO}_{2}$ sensors has recently been deployed that might allow for large scale verification of $\mathrm{CO}_{2}$ inversion models by monitoring for the entire atmosphere (pixels are integrated columns) for small changes in $\mathrm{CO}_{2}$ concentrations.

3.5 Specific methods and approaches for the fossil fuel/other-anthropogenic sector

There are two broadly cited data sets on $\mathrm{CO}_{2}$ emissions from fossil-fuel consumption, both updated approximately annually. The data set maintained by the International Energy

Fig. 5 This image of a tropical forest in Costa Rica demonstrates the capability of new airborne remote sensing instruments like LVIS to produce 3-dimensional representations of vegetation densities using imaging laser altimetry (Weishampel et al. 2000). This type of data can be calibrated with stand $\mathrm{C}$ inventories, allowing for large scale remote budgeting of forest $\mathrm{C}$

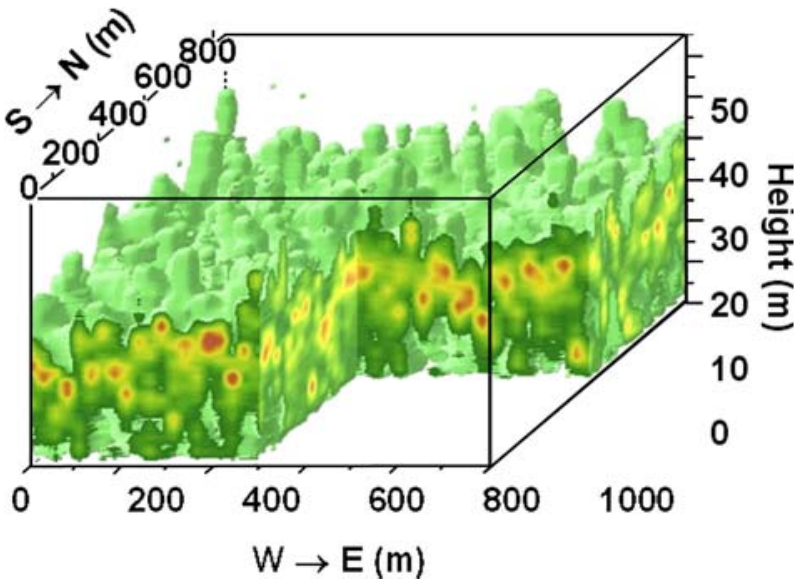


Agency (IEA) in Paris is based on its own compilations of world energy data and provides national and regional estimates of $\mathrm{CO}_{2}$ emissions back to 1971 (see http://www.iea.org). The data set maintained by the Carbon Dioxide Information and Analysis Center (CDIAC) at Oak Ridge National Laboratory is based largely on energy data compiled by the United Nations and provides national and regional estimates back to 1750 (http://cdiac.esd.ornl. gov/). The IEA data set includes considerable detail of emissions by economic sector. Both data sets estimate emissions using statistics on energy consumption (or apparent consumption) and coefficients that estimate $\mathrm{C}$ content per unit of fuel consumed. The data sets differ in small ways, including the way they treat non-fuel uses of fossil fuels, and they offer very similar estimates at the national and annual levels. These are founded in data that are collected from individual countries and shared between the UN and IEA. Marland et al. (1999) have analyzed in detail the differences in $\mathrm{CO}_{2}$ estimates from two different sources, one based on the IEA energy data and one based on the UN energy data. The CDIAC data set includes emissions from cement manufacture. Many countries are now reporting national estimates of $\mathrm{CO}_{2}$ emissions and these are compiled and summarized by the secretariat of the UN Framework Convention on Climate Change (http://www.unfccc.org).

Estimates of $\mathrm{CO}_{2}$ emissions at spatial and temporal scales finer than national and annual are more complex because of the scale at which fuel consumption data are normally collected. Andres et al. (1996) and Olivier and Berdowski (2001) have each estimated annual emissions on a 1 degree by 1 degree latitude/longitude grid by assuming that national emissions are distributed within each country as population is distributed. Some countries do have sufficient data on fuel consumption or fuel sales to permit estimates of $\mathrm{CO}_{2}$ emissions by state and/or by month. This type of analysis has so far been limited to a small number of countries e.g. Blasing et al. (2005a,b); (Losey 2004), and Gregg (2005). A project of the Association of American Geographers (AAG; http://www.aag.org/) has demonstrated the estimation of $\mathrm{CO}_{2}$ emissions for small geographic regions for which explicit fuel consumption data are not available. They assembled fuel consumption data for large point sources and then used proxy data such as vehicle miles travelled to estimate emissions from dispersed sources.

The general methods and approaches to quantify fluxes of $\mathrm{C}$ from fossil-fuel use are advanced and founded in the economics of fossil fuel extraction, transport and storage and the use of fossil fuels for energy production. National and regional energy balances as tools to quantify activities within the energy systems, distinguishing fuels, conversion technologies and fluxes of fuels as well as products originating from fossil fuels, have been refined for decades. Current trends in OECD countries towards liberalising energy markets, however, have caused a break in the transparency and reproducibility of energy balances on national scales, as market prices determine where for instance electricity is generated at a specific point in time, and which fuels might be used for the generation. At the same time, diverging political flows with regard to the phasing out vs extension of the use of nuclear fuels for electricity generation and first attempts to de-carbonise economies (e.g. with the use of hydrogen or methanol fuel cells) increase the uncertainties for forecasting future $\mathrm{C}$ contributions from the fossil fuel sector. In addition to that, flexible instruments within for instance, the Kyoto Protocol will most likely lead to regional shifts in fossil fuel consumption which are difficult to anticipate based on national or regional trend developments. Hence, forecasting, in particular the long-term development of this sector, is increasingly difficult with a number of possible and likely development paths that could emerge. 


\section{Sectoral data sources and gaps}

\subsection{Data for the forest sector}

For forests, practically all developed countries have designed and implemented a samplebased inventory in their forests, so data to ground-truth estimates are good. At these sample points (millions in the Northern Hemisphere), diameter and height of trees (usually 25) are measured at intervals of 5 to 10years. These data on stem-wood volume, in combination with remote sensing data for area assessment give an accurate data base. These inventories cover roughly 17 million $\mathrm{km}^{2}$ of forests (Fig. 6), although each inventory differs in accuracy and in the methods used. These inventories cover the types: 'boreal forest, cool conifer, temperate mixed and temperate deciduous forests'. Usually these inventories are lacking in developing countries, but this is partly compensated for by remote sensing devices, or a combination of technologies, as was done for the Amazon in the LBA project (Roberts et al. 2003). The wide implementation of ground-based inventories in developing countries is still some way off.

A more specific issue for forests is that inventories cover the stem-wood volume only, and often only the stock (i.e. not the increment). From these data, a number of sources of other data and modelling are applied to generate full system $\mathrm{C}$ balances. It is in these further steps that main uncertainties arise, both through gaps in the data and through the application of different approaches in different regions. One aspect that has received much attention is the use of biomass expansion factors (BEF). These are factors that convert from stem-wood volume to whole tree biomass dry weight. It is known that these differ by region, tree species and age. However, often the data required to define accurate BEFs are insufficient.

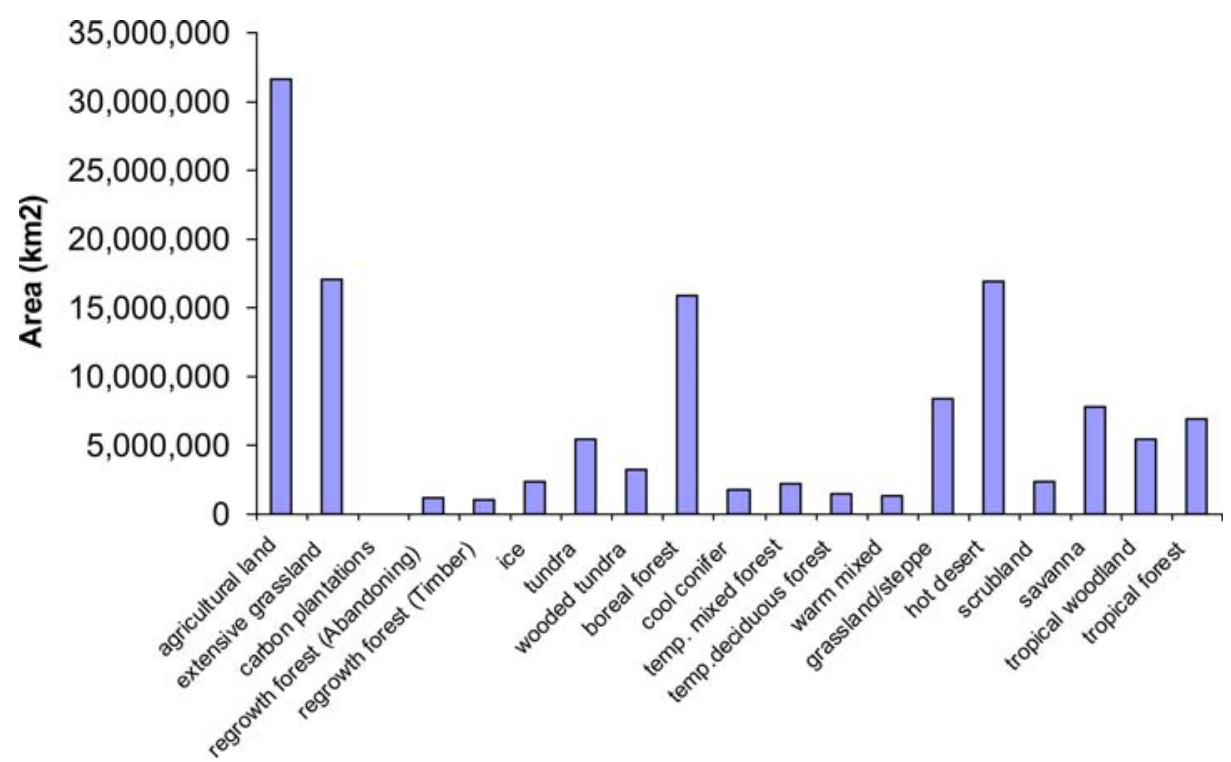

Fig. 6 Land cover by major vegetation type globally. Forests cover approximately 37 million $\mathrm{km}^{2}$ globally 
The time lag between a measure and its $\mathrm{C}$ impacts is also important for forests. For example, the forest owner may choose a certain tree species at establishment and this determines the $\mathrm{C}$ balance of that site for decades or centuries. Figure 7 shows this aspect at a larger scale: continental balances fluctuate through time with sources and sinks alternating at scales of decades. For example, the US shows a source in the 1850's around the time of fast colonisation (= deforestation). The sources of that time have set the pace for the sink at present, namely land abandonment around 1900 that led to large scale forest re-growth.

For forest inventories themselves, major advances can still be made in all of the tropical regions and in boreal Russia. Relatively cheap monitoring schemes would yield new insights in these regions. This, serving in combination with ground-truthing of satellite derived data (e.g. under GCOS) would bring great advances. However, the difficulties of the terrain, in combination with lack of capacity in many tropical countries, and the huge number of tropical tree species for which we lack the ecological understanding, make this a daunting endeavour. Furthermore, great advances can still be achieved through data mining in the grey literature (e.g. Phillips et al. 1998).

Additional data are needed to assess fully the global forest sector $\mathrm{C}$ budget, but most regions lack a consistent approach, and data are often of insufficient quality. The outlook for satellite-derived data is better, in that there is, in principle, the same quality and regional and temporal coverage worldwide. This is a great advantage. However, the use of satellite-derived data beyond simple area assessment is still highly disputed. For this reason, the assessment in Table 2 is good, but with the caveat that an actual $\mathrm{C}$ balance assessment from these data is still some way off. The full balance assessment can better be assessed at the site level using eddy covariance methods, but the spatial coverage is very limited. Few countries (e.g. North America, Europe, China) have strong spatial forest network coverage.

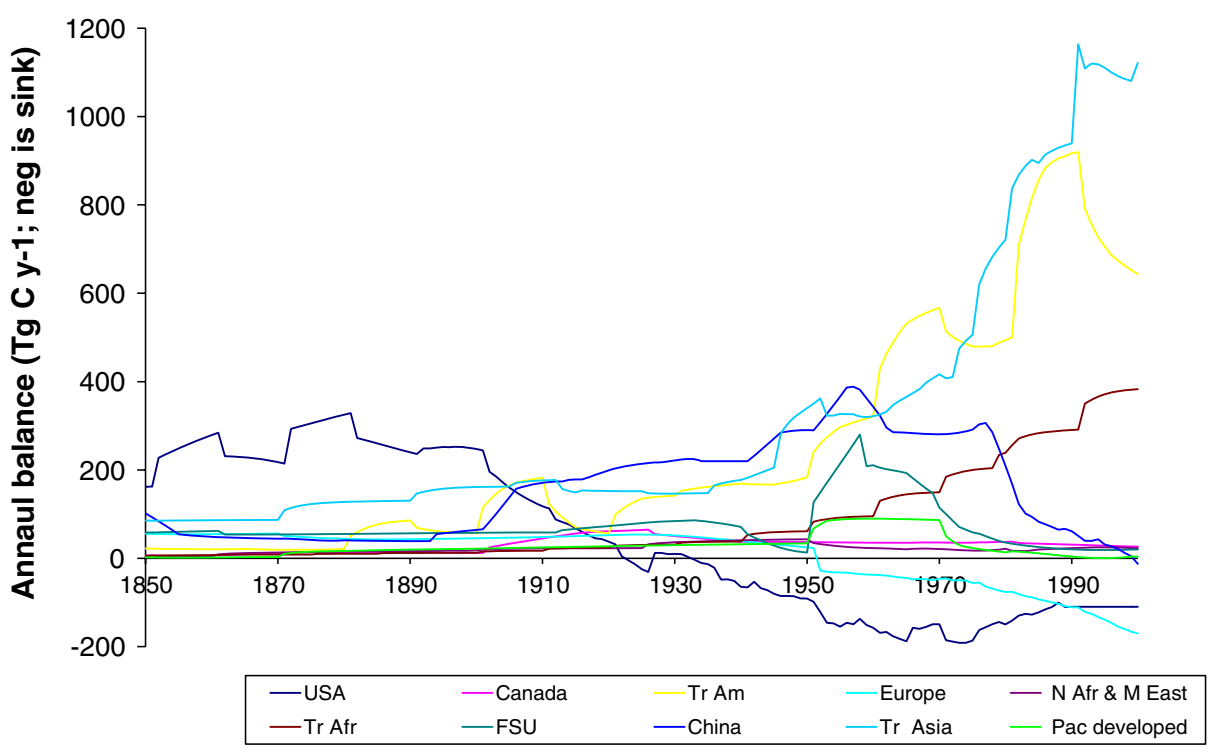

Fig. 7 Carbon balance of the LULUCF sector (often forests alone) per continent, historically IPCC (2000) 
Table 2 Overview of data quality for forest sector $\mathrm{C}$ budgeting

\begin{tabular}{|c|c|c|c|c|}
\hline & $\begin{array}{l}\text { Data quality of } \\
\text { forest inventory }\end{array}$ & $\begin{array}{l}\text { Data quality on other } \\
\text { variables than stemwood } \\
\text { volume, e.g. BEF's, soils, } \\
\text { wood products }\end{array}$ & $\begin{array}{l}\text { Data quality of } \\
\text { eddy covariance }\end{array}$ & $\begin{array}{l}\text { Data quality of } \\
\text { satellite derived data }\end{array}$ \\
\hline Canada & 0 & + & 0 & + \\
\hline USA & + & + & 0 & + \\
\hline Oceania & + & 0 & - & + \\
\hline Japan & + & 0 & 0 & + \\
\hline OECD Europe & + & 0 & 0 & + \\
\hline Greenland & - & - & - & + \\
\hline Eastern Europe & 0 & 0 & - & + \\
\hline Former USSR & 0 & - & - & + \\
\hline Western Africa & - & - & - & + \\
\hline Eastern Africa & - & - & - & + \\
\hline Southern Africa & - & - & - & + \\
\hline Middle East & - & - & - & + \\
\hline Northern Africa & - & - & - & + \\
\hline Central America & 0 & - & - & + \\
\hline South America & 0 & - & 0 & + \\
\hline East asia & + & 0 & - & + \\
\hline South Asia & 0 & - & - & + \\
\hline South East Asia & + & - & - & + \\
\hline
\end{tabular}

+ good; 0, fair; -, bad

Based on a variety of sources, and expert best guesses

\subsection{Data for the agricultural sector}

The regions in which there are already estimates of the $\mathrm{C} / \mathrm{GHG}$ flux from agricultural lands are North America (USA and Canada; Parton et al. 2005; McConkey et al. 2008), Australia (NCAS 2002) and New Zealand (Tate et al. 2000) and Europe (Vleeshouwers and Verhagen 2002; Janssens et al. 2003, 2005). Other countries within Asia (e.g. Japan - Nishimura et al. 2004; China - Yan et al. 2003; Zheng et al. 2004; India - Bhatia et al. 2004) have estimates, as do some countries in Latin America (Alvarez 2001). In many regions, particularly in developing countries, estimates do not exist, and the data to make such estimates are not well developed. For UNFCCC national greenhouse gas inventory submissions, some estimates of $\mathrm{N}_{2} \mathrm{O}$ fluxes from soil are made, but the full GHG budget for the agricultural sector has not been assessed for most developing countries. Some of the challenges for cropland data collation are discussed below.

Crop growth and yield Regional or sectoral budgets often require knowledge of crop growth or yields. These are either used directly in calculating the $\mathrm{C}$ budget $(\mathrm{C}$ import and export) or may be used by agro-ecological models as an input or as model validation/ evaluation data. Crop statistics are of variable quality between regions and for some regions are not collected routinely. Where the data do exist, historical data on crop yield are often aggregated over large areas (e.g. to countries, as in the FAO database) and are not spatially explicit. This means that variability in yield in different regions, or due to different soils types for example, cannot be assessed. Further, it is difficult to allocate these statistical 
descriptions of yield to spatially explicit areas. This is a key challenge when construction many spatially explicit datasets. Other datasets are often required to perform these allocations and uncertainty is introduced. For the recent past and for the future, remote sensing promises to greatly improve our capability for producing spatially explicit datasets for crop growth and yield (Lobell et al. 2002, 2003). In contrast with arable crops, there are very few statistics available for grassland productivity. Proxies such as the animal stocking density per unit grassland/rangeland area can be calculated. Nevertheless, in intensive livestock breeding areas, the diet of domestic herbivores includes a large fraction of concentrate feeds and roughage, inputs that are purchased rather than produced on farm. Hence, there is no direct relationship between the animal stocking density, as estimated from regional statistics, and the actual grazing pressure.

Soil and climate Spatial databases of soil and climate have greatly improved in some regions in recent years. The techniques for improving the spatial resolution of the datasets in these regions could be applied to other regions in the future, but poor coverage of historical climate data and soil sampling may limit the applicability of these techniques which were developed in relatively data-rich regions.

Historical land-use and management Historical land use is often unknown or very poorly defined. When modelling changes in SOC, historical land-use can have a great impact. It has been shown, for example, that management impacts can lead to measurable differences is SOC over 100years after they cease (Jenkinson 1988; Smith 2005). Historical land-use reconstructions are often made at the global scale (Ramankutty and Foley 1999) which are then downscaled to finer temporal and spatial resolution using country level or regional land-use statistics (S. Zaehle, personal communication). Land-use transition matrices can be made at large spatial scales (e.g. Cannell et al. 1999) but cannot be allocated at the fine spatial scale. Other problems associated with non-remote sensed data for land-use transitions arise from inconsistencies in survey land-use categories and methods used in the consecutive surveys (Cannell et al. 1999). Fine scale allocations of land-use change can be made using remote sensing data, but there is often little suitable remote sensing data available before the 1970s (and often later). The significant problems highlighted for land use are many times worse for land management. In most regions, data on management techniques (fertilization, tillage, rotations etc.) simply are not collected. In some regions, e.g. North America, detailed management data has begun to be collected in recent years (e.g. CTIC 2006), but in many regions it has to be inferred from expert knowledge (e.g. Smith et al. 2000). In the very few regions in which management data does exist, it is often statistical in nature. As with land use, it is difficult to allocate these aggregated statistical data to specific areas in a spatial database. Since management is a key driver of cropland C cycling and GHG emissions, there is a pressing need to collect spatially explicit data of cropland and grassland management practices.

A grassland typology was developed for C inventories by the IPCC (2003) that separates degraded grasslands (e.g. overgrazed, less productive), nominally managed (e.g. pasture and rangelands with no grazing problems or inputs, native vegetation) and improved grasslands with medium/high inputs (e.g. sown grasses and legumes, fertilizer supply, liming, irrigation). While these general categories are useful, they need to be adapted in each region. Regional typologies of grasslands and rangelands thus need to be further developed, taking into account not only the soil and vegetation types, but also the animal stocking density, the organic and inorganic fertiliser application, the number and timing of harvests etc. 
Future projections for forecasting Projections of future climate are relatively well developed, though different climate models have been shown to result in differences in changes in SOC as large as the differences between different emission scenarios (Smith et al. 2005). Projections of potential yield change due to technological improvement (Ewert et al. 2005) and land-use (Rounsevell et al. 2005) are in their infancy. Significant uncertainties are known, and a scenario-based approach is often taken (Rounsevell et al. 2005). The reliability of future projections depends critically upon the reliability of the scenario data used to run models, so databases of future changes need to be robust and used with care. In addition to scenario uncertainty, model uncertainty is also important. In recent projections of SOC changes in European croplands and grasslands over the next century, quantified uncertainty was found to be $33-100 \%$ of the projected SOC stock change (Smith et al. 2005). Lastly, data on environmental stresses such as drought, flooding and pest outbreaks are often very poor or non-existent.

Priorities for future research in the agricultural sector include (a) systematic and coordinated attempts to measure non- $\mathrm{CO}_{2}$ gas fluxes from the agricultural sector, (b) more research on the management/agricultural impacts on the whole (C plus GHG) budget, (c) projections of how agricultural lands will respond to environmental change. For regional budgets, programmes of research should be carried out on an area-specific basis.

\subsection{Data for wetlands/peatlands}

Global extrapolations need to reconcile estimates made by LORCA and current fluxes/ transport and must consider $\mathrm{CH}_{4}$ fluxes and DOC losses. Though data is better developed in Europe and North America, such data are sparse at the global scale. For C stock estimates, data on the density and distribution of peat and determination of peat depth are often lacking. For atmospheric flux measurements, northern wetland and permafrost ecosystems are relatively well covered with a reasonable spread across the circumpolar North (e.g. Oechel et al. 2000; Nordstroem et al. 2001; Aurela et al. 2002; Lafleur et al. 2003; Friborg et al. 2004; in prep.; Corradi et al. 2005), whilst more $\mathrm{CO}_{2}$ and $\mathrm{CH}_{4}$ flux monitoring stations in tropical wetlands are needed. The few studies on GHG emissions from tropical peatlands have usually focused on non- $\mathrm{CO}_{2}$ gases, such as methane and nitrous oxide, and in these, emission rates can be higher (Hadi et al. 2000, 2005) than rates from continuously irrigated rice grown on mineral soils (Husein et al. 1995; Suratno et al. 1998). These data are available for Indonesia, but comparable monitoring in South America, Africa and East Asia should be a high priority.

In the discontinuous permafrost zone in the North there are huge stores of organic $\mathrm{C}$ and the stability of this as a terrestrial $\mathrm{C}$ store is dependent on the climate. There is evidence now that serious losses of stored $\mathrm{C}$ may currently be taking place due to melting of permafrost and the subsequent thermokarst erosion and landscape scale vegetation change that appear in peatlands (Christensen et al. 2004; Malmer et al. 2005). This factor may play a large role in the global climate system but is, as yet, very poorly understood.

\subsection{Data for fossil fuels/other anthropogenic sectors}

In contrast to natural and biogenic sources of $\mathrm{C}$ emissions, the anthropogenic part of the $\mathrm{C}$ cycle is economically important and thus rather well documented by statistics, for instance detailed energy balances, commodities traded on energy markets, installed capacities for electricity generation and their utilisation, and so forth. Individual estimates require specific datasets, e.g. detailed energy balances, passenger mileage etc. to quantify sectoral 
emissions; and the data available will depend very much on the temporal and spatial scale at which estimates are sought.

It is difficult to assess future trends in emissions on a global scale because emissions depend on both the energy demand and the way in which this demand is met. Both the rate of growth and the fuel supply will vary among countries and regions and they typically are a function of sector, technology, fuel resources available, region and political framework. Examples include nuclear energy, which is being phased out in European countries while there is a global increase in utilisation of nuclear power, and the growing total energy demand in developing and transition countries vs a stagnation or decrease in OECD countries.

For the fossil fuel/other anthropogenic sector, regional data are available from a number of institutions, e.g. OECD, IEA, UN. However, data availability varies significantly with region and sector, with robust and detailed datasets mostly available for the industrialized countries and for sectors dominated by large point sources of emissions. A main issue is that data are available in good quality mainly for countries with moderate to low growth rates and comparatively small increases/changes to be anticipated for fossil fuel consumption in the near and distant future, whereas data (quality) is worse for those regions where a significant growth in fossil fuel use is to be projected, both due to economic growth and population development. On the other hand, with a few exceptions, good data are generally available for those countries with the largest current emissions (Fig. 8). For the time being, data for OECD countries typically allow for a quantification of C fluxes from fossil-fuel use with very high temporal and spatial resolution (see Fig. 9), whereas for large regions in particular in Africa and South-East Asia, it is even difficult to estimate overall annual figures for the whole region. The comparisons of Marland et al. (1999) reveal the importance of having good data for the largest sources: although the two estimates of $\mathrm{CO}_{2}$ emissions from the US differed by only $0.9 \%$, the absolute magnitude of this difference was larger than the total emissions from 147 countries.

(Mtoe)

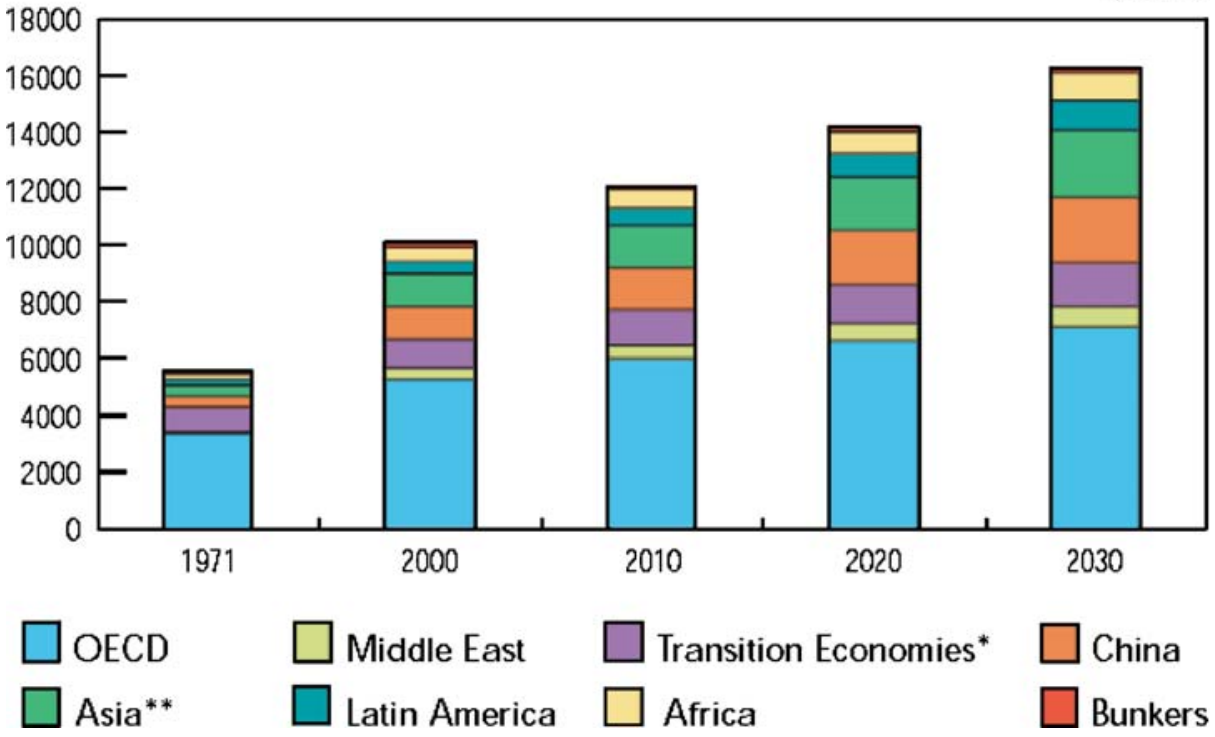

Fig. 8 World development of total primary energy supply region as projected by IEA (Source: IEA Key World Energy Statistics, 2004 Edition, http://www.iea.org) 

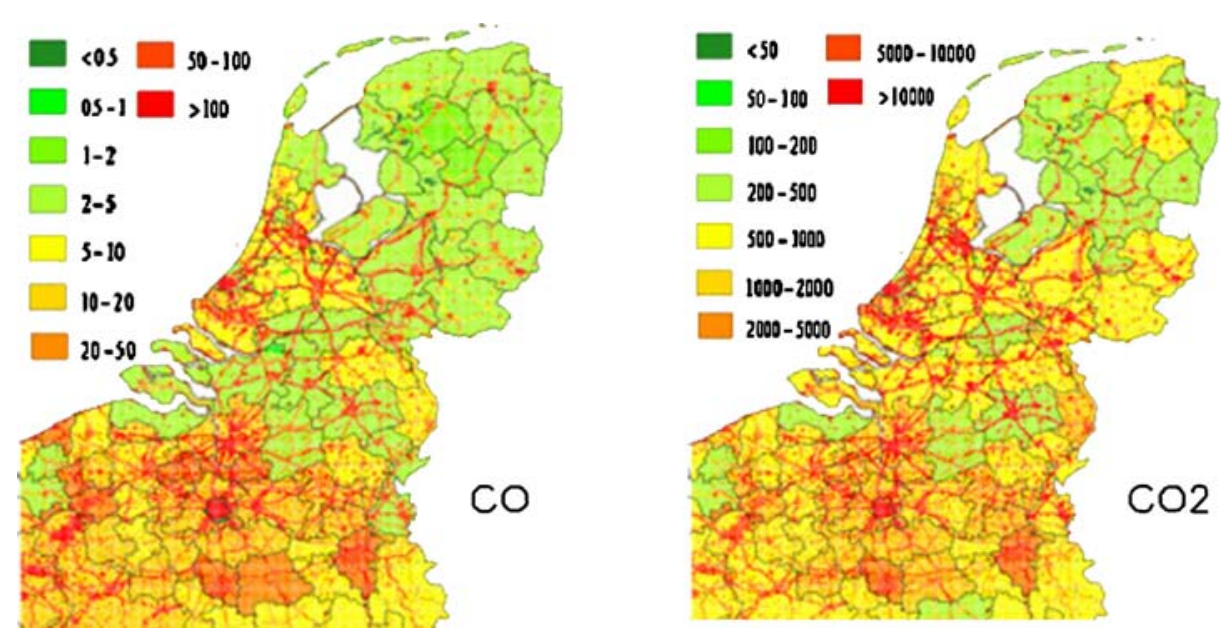

Fig. 9 Spatially resolved emissions $(1 \times 1 \mathrm{~km})$ of $\mathrm{CO}_{2}$ and $\mathrm{CO}$ for The Netherlands for the year $2000 \mathrm{using}$ advanced methods for spatial (and temporal, hourly resolution available) disaggregation of data on road and rail networks, large point sources and area sources (Source: IER University of Stuttgart for the CarboEurope IP project, http://carboeurope.ier.uni-stuttgart.de)

In some regions (e.g. Europe), the globalization of energy markets causes an increase in uncertainty with regard to the temporal and spatial patterns of fossil fuel consumption and thus of $\mathrm{CO}_{2}$ emissions. With energy grids spanning whole regions and energy transfers across regions (e.g. biofuels, potential hydrogen production, divergent trends in nuclear generation capacities etc.) in decentralized systems, uncertainty ranges on the time and space of $\mathrm{C}$ releases might significantly increase while at the same time data quality and availability improve. A similar issue is that of trans-national and trans-regional transport (land, air, sea) and the spatial representation of fuel consumption and hence $\mathrm{C}$ release accounting. Blasing et al. (2005b) have shown, for example, that per-capita emissions differ by an order of magnitude among US states, largely because of the inter-state transport of electricity from coal-fired power plants and of other energy-intensive products such as fertilizer and refined-petroleum products. Methods for an accurate and comprehensive spatio-temporal representation of mobile sources have to be developed/improved. Further to that, emerging technologies for a de-carbonisation of economies creates significant uncertainties for forecasting. Finally, with the Kyoto protocol entering into force and flexible mechanisms allowing for emission trading between Annex I countries, C may turn into a traded commodity with implications for the accountability of $\mathrm{C}$ releases and their inter-annual variability that cannot be quantified yet.

As the methods are mainly constrained by data availability, focus should be on the regions and sectors where data is non-existent or of poor quality, and on completeness, i.e. trying to identify energy/material flows which are not accounted for yet.

\section{Examples of regional sectoral GHG budgets}

\subsection{The sectoral GHG budget for European forests}

Estimates of the European forest GHG budget (Fig. 10), clearly shows the uncertainty that still remains for an intensively studied region. The inventory-based methods agree well, but 


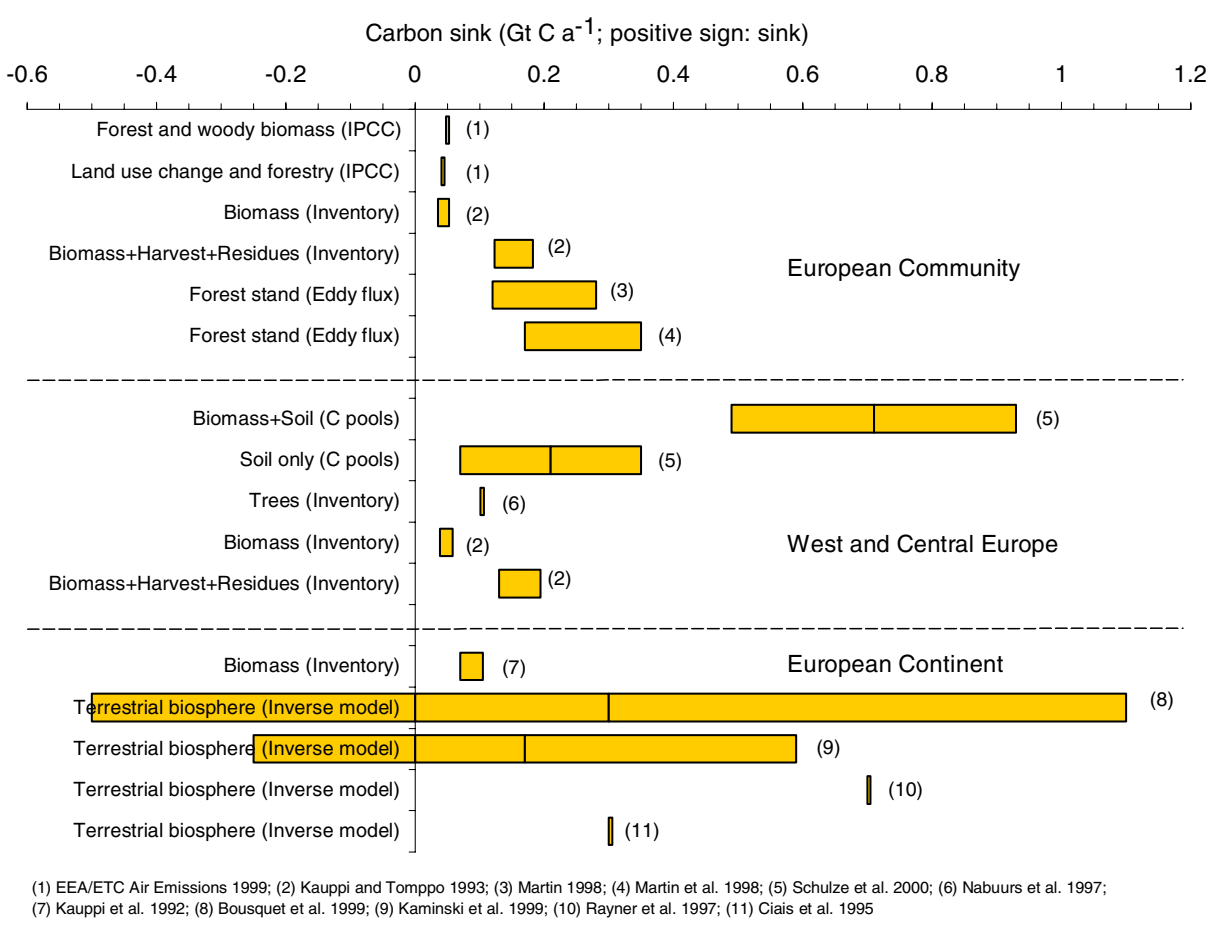

Fig. 10 Estimates of the $\mathrm{C}$ sink in European forests (based on national submissions, Ciais et al. 1995; Martin 1998, Bousquet et al. 1999; Nabuurs et al. 1997, 2002; Valentini et al. 2000, FAO/FAO 2000, Païvinen and Anttila 2001)

when taking into account the other methods used, the spread in assessment results becomes very large. A later study by Janssens et al. (2003) reduced this spread in estimates to a factor of 2. By compiling a number of regional assessments, Goodale et al. (2002) found that forests and woodlands in the Northern Hemisphere (Fig. 11) provided a total sink of 0.6-0.7 Gt C per year during the early 1990s. This could not account for the $2.5 \mathrm{Gt} \mathrm{C}$ "missing sink" on land. In order to improve these estimates, more integrated approaches are required, e.g. by combining forest wood resource modelling with $\mathrm{C}$ balance studies, climate change impacts, as well as scenarios that depict forest management trends (Figs. 12 and 13).

\subsection{The sectoral GHG budget for agriculture}

Some regional C/GHG budgets exist. For example, greenhouse gas emissions in 1990 and 2000 for EU-15 were estimated to be as follows: nitrous oxide-1990: $60 \mathrm{Mt} \mathrm{C}$-equivalents year $^{-1}$, nitrous oxide-2000: 57 Mt C-equivalents year ${ }^{-1}$, methane-1990: 54 Mt C-

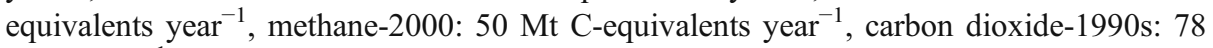
Mt C year ${ }^{-1}$ (Smith 2004a, b, c). Greenhouse gas emissions in China were estimated to be

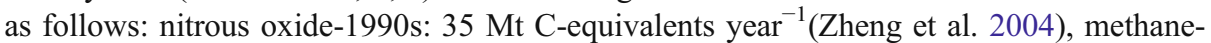
1995: 37-61 Mt C-equivalents year ${ }^{-1}$ (Yan et al. 2003). NPP of croplands in mainland China was estimated to be $490 \mathrm{Mt} \mathrm{C}$ year $^{-1}$ in 1990s (Huang et al. 2004b).

Net Primary Production of croplands ( $\mathrm{C}$ uptake by photosynthesis less autotrophic respiration) can be estimated using agricultural statistics (yields and cropped area) and 


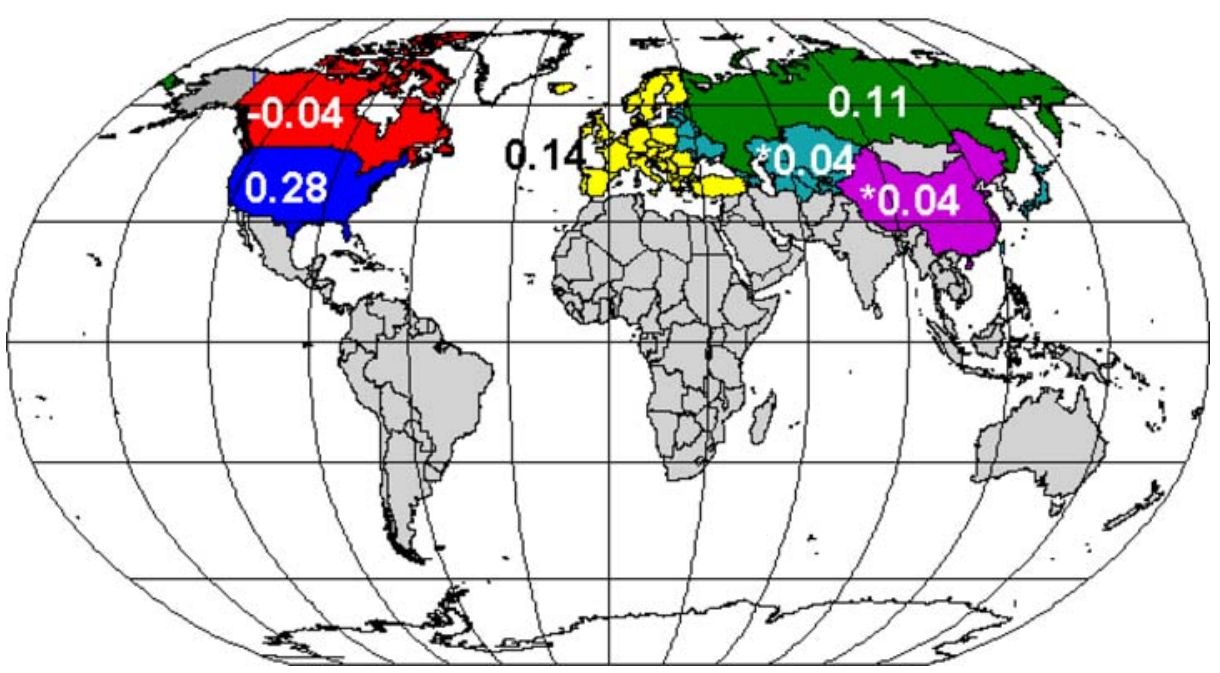

Fig. 11 Forest sector net $\mathrm{C}$ sources $(-)$ and sinks $(+)\left(\mathrm{Pg} \mathrm{C}_{\mathrm{year}}{ }^{-1}\right)$. Asterisk indicates net change in tree stocks; other values pertain to whole sector balance (from Goodale et al. 2002)

biomass partition indices. Following this approach Hicke et al. (2004) estimated a mean NPP of $0.45 \mathrm{Pg} \mathrm{C}_{\text {year }}{ }^{-1}$ in the conterminous US in the period 1972-2001. They also found a linear positive trend, with NPP increasing $~ 40 \%$ during the 30years analysed. This increase in NPP was caused mainly as a consequence of an increase in NPP per area unit, as total cropland area in the US remained unchanged. Several causes lie behind this trend, such as more effective fertilization, use of higher yielding cultivars and shifts to more productive crops. A similar temporal trend was found by Guerschman and Paruelo (unpublished) in the Argentine pampas.

The UNFCCC reports the amount of GHG emissions from assessments performed by each country, following a meticulous methodology. The agriculture sector emitted in average $2.7 \times 10^{6} \mathrm{Gg}_{\text {year }}{ }^{-1}$ of $\mathrm{CO}_{2}$-equivalents in the period 1990-2002. Latin America and the Caribbean was the region with the highest amount of mean GHG emissions per year

Fig. 12 Development of the forest area average NBP $\left(\mathrm{Mg} \mathrm{C} \mathrm{ha}^{-1}\right.$ year $\left.^{-1}\right)$ for 27 European countries included in the study until 2050 under current and changing climatic conditions when $\mathrm{BaU}$ (traditional forest management) and MultiF (nature oriented forest management) scenarios were applied. The study reveals that under all cases, the sink will slightly saturate in Europe, but the forests will still be a sink until 2050 (Karjalainen et al. 2003; Nabuurs et al. 2002)

\section{NBP in Europe}

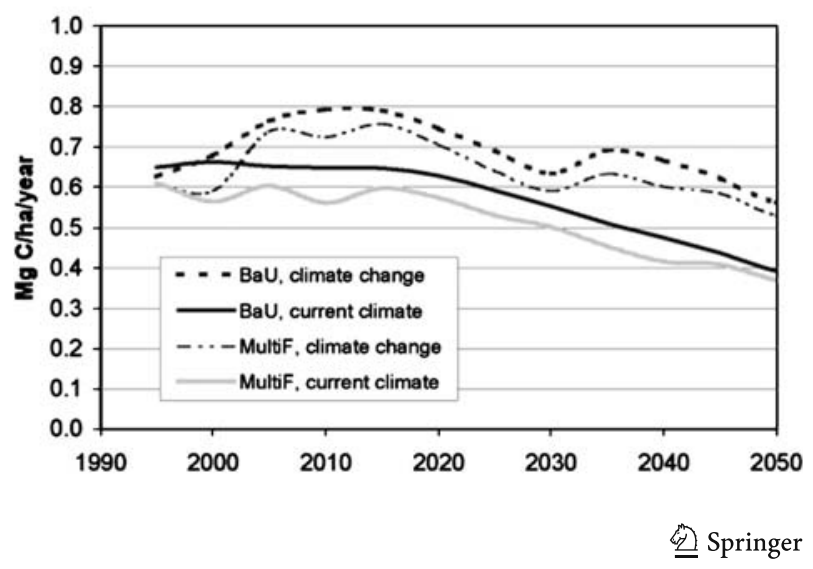




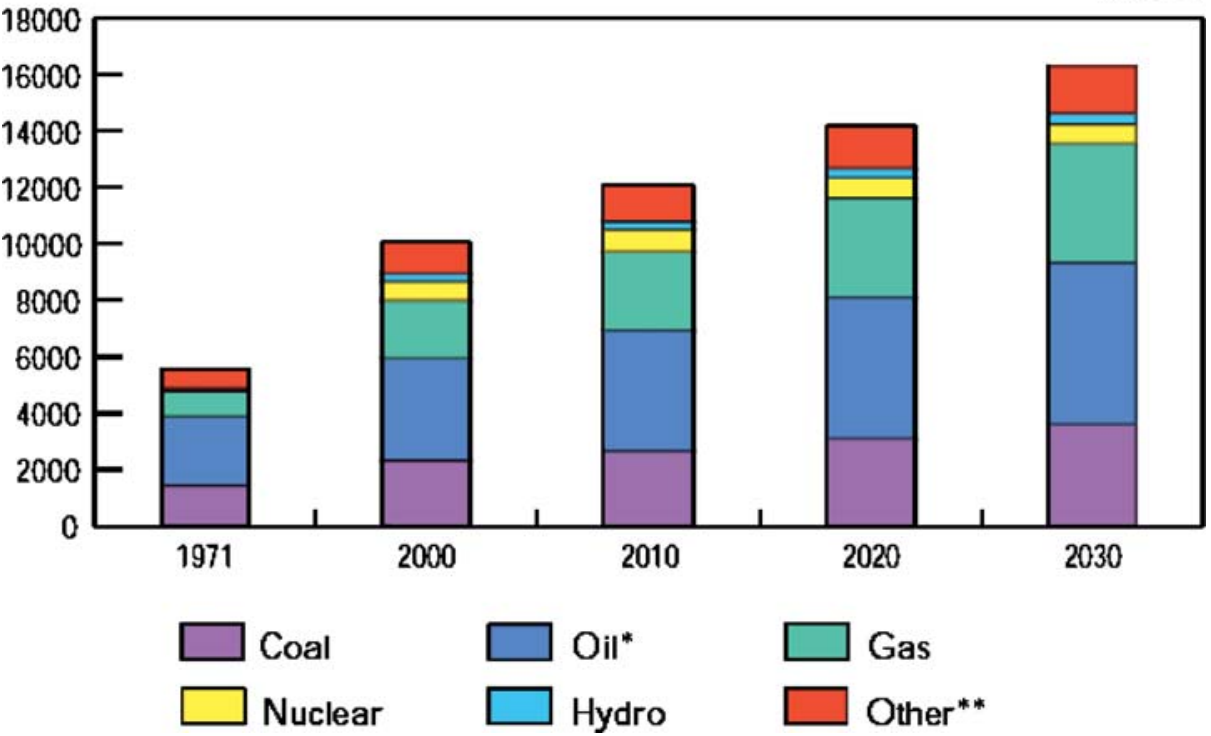

Fig. 13 World development of total primary energy supply by fuel as projected by IEA (Source: IEA Key World Energy Statistics, 2004 Edition, http://www.iea.org)

$\left(5.8 \times 10^{5} \mathrm{Gg}_{\text {year }}{ }^{-1}\right.$ of $\mathrm{CO}_{2}$ eq $)$, followed by North America $\left(5.2 \times 10^{5} \mathrm{Gg}\right.$ year $^{-1}$ of $\mathrm{CO}_{2}$ eq), the European Union $\left(4.9 \times 10^{5} \mathrm{Gg}_{\text {year }}{ }^{-1}\right.$ of $\mathrm{CO}_{2}$ eq $)$ and Asia $\left(4.5 \times 10^{5} \mathrm{Gg}\right.$ year $^{-1}$ of $\mathrm{CO}_{2}$ eq). This analysis, however, does not include some countries that have large amounts of GHG emissions, because these countries have not completed the GHG reports. For instance, the values reported above do not include China, India and Brazil, three of the largest countries of the world, both in cropland area and livestock number. The two gases that account for by most of the emissions are $\mathrm{CH}_{4}(53 \%)$ and $\mathrm{N}_{2} \mathrm{O}(43 \%)$, while $\mathrm{CO}$ accounts for by the remaining $4 \%$. There are no $\mathrm{CO}_{2}$ emissions reported for the agriculture sector because the IPCC methodology assumes that the production and decomposition fluxes are balanced (IPCC 1997).

\subsection{The sectoral GHG budget for Indonesean peatlands}

Globally, peatlands cover an area of around 400 Mha, of which $10 \%$ are located in tropical regions (Maltby and Immirizi 1993). Indonesia contains an estimated 16 Mha or roughly $80 \%$ of the peatlands in Southeast Asia region. Maltby and Immirizi (1993) estimated that peatlands store $329-525 \mathrm{Gt} \mathrm{C}$ or $15-35 \%$ of the total terrestrial C, one fifth of which (70 $\mathrm{Gt}$ ) is located in the tropics. By assuming that the mean depth of Indonesian peatlands is 5 $\mathrm{m}$, with a bulk density of $0.12 \mathrm{~g} \mathrm{~cm}^{-3}$ and $\mathrm{C}$ content of 50 percent there are about $46 \mathrm{Gt} \mathrm{C}$ stored in the peatlands. Furthermore, Neuzil (1997) estimated that the annual C accumulation rate in Indonesian peatland ranges between $59-118 \mathrm{~g} \mathrm{~m}^{-2}$ (or between 0.01 and $0.03 \mathrm{Gt} \mathrm{C}$ ), which is much higher than the accumulation rates in temperate or boreal zones, which ranges between 20 and $100 \mathrm{~g} \mathrm{C} \mathrm{m}^{-2}$ year $^{-1}$ in addition to the sequestration rates of $8-80 \mathrm{~g} \mathrm{C} \mathrm{m}^{-2}$ year $^{-1}$. The fixation in the tropics may reduced up to $5 \mathrm{Mt}^{\text {year }}{ }^{-1}$ when the ecosystems are disturbed (Sorensen 1993). 
Recently, fires have increasingly become important factors in the global C cycle, including in the tropical peatland ecosystems. The 1997/98 Indonesian fires involved 2.12 Mha of peatlands or $10 \%$ of the total peatland area in Indonesia (Tacconi 2003; Murdiyarso and Adiningsih 2008). Page et al. (2002) estimated that between 0.81 and $2.57 \mathrm{Gt}$ of C were released to the atmosphere by 1997/98 fires. Murdiyarso and Adiningsih (2008) estimate that $1.45 \mathrm{Gt}$ of $\mathrm{C}$ was released during that period and $0.47 \mathrm{Gt}$ were contributed by peatland fires.

\subsection{The sectoral budget of European peatlands}

Currently peatlands in Europe are estimated to hold ca. $42 \mathrm{Gt} \mathrm{C}$ in the form of peat (Christensen and Friborg 2004) and are therefore a considerable component in the European $\mathrm{C}$ budget. They are also significant emitters of methane and in some cases also of nitrous oxide. A best estimate for all the European countries shows that some are currently sinks for atmospheric $\mathrm{CO}_{2}$ while others are sources. In contrast, for $\mathrm{CH}_{4}$ and $\mathrm{N}_{2} \mathrm{O}$, only the sources are relevant. Whilst some countries are $\mathrm{CO}_{2}$ sinks, all countries are net GHG emitters from peatlands. A synthesis of GHG exchange in European peatlands (Christensen and Friborg 2004) indicates some interesting features. Russia hosts an estimated $41 \%$ of European peatlands and contributes most to all GHG exchanges $\left(\mathrm{CO}_{2}: 25 \%, \mathrm{CH}_{4}: 52 \%\right.$, $\mathrm{N}_{2} \mathrm{O}: 26 \%$, Total: $37 \%$ ). Germany is the second-largest emitter (12\% of European total) although it contains only $3.2 \%$ of European peatlands. The reason is the use of most of the peatland area for intensive cropland and grassland. The largest $\mathrm{CO}_{2}$ emitters are countries with large agricultural peatland areas (Russia, Germany, Belarus, Poland), the largest $\mathrm{N}_{2} \mathrm{O}$ emitters are those with large agricultural fen areas (Russia, Germany, Finland). In contrast, the largest $\mathrm{CH}_{4}$ emitters are concentrated in regions with large areas of intact mires, namely Russia and Scandinavia. High average emission densities above $3.5 \mathrm{t} \mathrm{C}$-equiv. ha ${ }^{-1}$ are found in the Southeast Mediterranean, Germany and the Netherlands where agricultural use of peatlands is intense. Low average emission densities below $0.3 \mathrm{t} \mathrm{C}$-equiv. ha ${ }^{-1}$ occur where mires and peatland forests dominate, e.g. Finland and the UK (Christensen and Friborg 2004).

The EU report on peatland C and GHG emissions (Christensen and Friborg 2004) arrived at much the same conclusion as early inventories of Canadian peatlands in a Kyoto context (Roulet 2000) where the lack of concrete data from basic emission studies in different climatic zones and under different management schemes are pointed at as a current problem for potential accounting in a post-Kyoto context.

\section{Opportunities for $\mathrm{C}$ management}

\subsection{Opportunities for $\mathrm{C}$ management in forests}

Forest sector $\mathrm{C}$ budgets have been paid a lot of attention for several reasons: (1) forests have a large aboveground biomass and seem to be a suitable land use for $\mathrm{C}$ sequestration, (2) large emissions occur from deforestation in the tropics, and (3) forests cover around $30 \%$ of the total global land area, and in many regions this area in increasing. Management options in forestry to reduce $\mathrm{C}$ emissions or to increase $\mathrm{C}$ stocks arise from reduction in deforestation, afforestation and various forest management practices included silvicultural management (e.g. alternative thinning regimes, reduced impact logging), pest and fire control, planting of alternative species/communities. Such is the potential for emission 
reduction in forests that they appear as mandatory $\mathrm{C}$ sinks/sources (for industrialised, "Annex 1" countries) under article 3.3 of the Kyoto Protocol.

\subsection{Opportunities for $\mathrm{C}$ management in agricultural lands}

There are many opportunities for $\mathrm{C}$ management (and non- $\mathrm{CO}_{2} \mathrm{GHG}$ mitigation) in agricultural lands. There have been many reviews including Cole et al. 1996; Paustian et al. 1998; Lal 2004; Smith 2004a, b; Smith et al. 2007a). Agricultural mitigation options, as well as the per area mitigation potential estimate, are shown in Table 3 below (Smith et al. 2007a).

Agricultural ecosystems are among the most intensively managed of all and often have been depleted in SOC. There is significant potential for soil $\mathrm{C}$ sequestration in croplands (globally estimated to be about $0.9 \pm 0.3 \mathrm{Pg} \mathrm{C}$ year $^{-1}$; Lal 2004) and some in grasslands (Follett 2001). Further, management practices lead to significant fluxes of non- $\mathrm{CO}_{2} \mathrm{GHGs}$, particularly nitrous oxide (Robertson 2004), meaning that there is significant potential to alter management to reduce this flux. The mitigation options outlined in Table 3 clearly have the biological potential to significantly reduce C and GHG fluxes to the atmosphere, but their effectiveness will be limited by social, economic, political and institutional constraints (Smith 2004b; Smith et al. 2007b).

Lal (2004) estimated a potential rate of $\mathrm{C}$ sequestration of rangelands and grasslands comprised between 0.01 and $0.3 \mathrm{Gt} \mathrm{C}$ year $^{-1}$ for 3.7 billion ha in semi-arid and sub-humid regions. Follett and Schuman (2005) reviewed grazing land contributions to $\mathrm{C}$ sequestration worldwide using 19 regions. Based upon grazing animal production, it might be assumed that forage production per unit of pasture area would be higher with improved inputs and grazing management, which would in turn increase the potential SOC sequestration rate. Follett and Schuman (2005) determined that the rate of SOC sequestration from Conant et al. (2001) was, on average, related by a quadratic regression to the meat production from grazing animals per unit of permanent pasture. This relationship excluded data from Australia and China which were outliers. Given the high variability within a region of soil and climate factors, it cannot be expected to match $\mathrm{C}$ sequestration in all soils. However, it does indicate a positive relationship, on average, between the $\mathrm{C}$ sequestration rate and the animal stocking density. Based on this relationship they estimate a 0.2 Gt SOC sequestration/year on 3.5 billion ha of permanent pasture worldwide. Using national grassland resource dataset and NDVI time series data, and assuming a constant ratio of aboveground to belowground biomass for each grassland type, Piao et al. (2007) estimated that the total (above- and below-ground) biomass $\mathrm{C}$ stocks of China's grasslands increased by $126.67 \mathrm{Tg} \mathrm{C}$ over the past two decades, with an increase of $7.04 \mathrm{Tg} \mathrm{C}$ year $^{-1}$.

A meta-analysis of 115 studies in pastures and other grazing lands worldwide (Conant et al. 2001), indicated that soil $\mathrm{C}$ levels increased with improved management (primarily fertilisation, grazing management, and conversion from cultivation or native vegetation) in $74 \%$ of the studies considered. Soil C sequestration is generally greater under grazed pastures than under cut pastures (Franzluebbers et al. 2000). To increase SOC sequestration on rangelands generally requires improved grazing management, introduction of legumes, and control of undesirable species. In temperate regions, like Europe, SOC sequestration would be favoured by grazing compared to cutting and by a close to optimal $\mathrm{N}$ fertilizer application. However, this $\mathrm{N}$ fertilizer supply also increases strongly the $\mathrm{N}_{2} \mathrm{O}$ emissions from soils. Moreover, increasing the animal stocking density also leads to greater methane emissions from enteric fermentation (Vuichard et al. 2004) as well as greater $\mathrm{N}_{2} \mathrm{O}$ 
emissions from localised patches of high available $\mathrm{N}$ concentration due to animal excretion (Saggar et al. 2004).

\subsection{Opportunities for $\mathrm{C}$ management in peatlands/wetlands/permafrost}

Fire prevention, water management, controlling climate change (permafrost issue), and limiting the opening of new areas for peat extraction and other uses all have the potential to either increase $\mathrm{C}$ storage or reduce $\mathrm{C}$ loss. While new areas of pristine peatlands in Europe are unlikely to be subject for industrial use, a study carried out in eight provinces of Sumatra indicated that most peatlands are located in state forest lands which often involve public decisions in the allocation for development and conservation purposes. They are very vulnerable to rapid and possibly irreversible degradation with intensive deforestation, draining and land conversion. The increased human activity also makes them susceptible to repeated burning that causes loss of $\mathrm{C}$ and biodiversity. Associated resource changes including fisheries production cause major shifts and adaptations in local livelihoods. Managing peatland $\mathrm{C}$ may be approached in two ways. The management in conservation areas could be related to payment for ecosystem services, by which conservation activities may be financed. In areas where the community is dependent on the peatland resources, the management should incorporate community development.

Peatlands in permafrost regions are extremely sensitive to climate change but in terms of management issues there are very few direct measures that can be taken to mitigate the impacts on these ecosystems of the changing climate. In Europe alone the unique ecosystem type which is dependent on permafrost, the palsa mires, are diminishing rapidly in their extent (Luoto et al. 2004; Christensen et al. 2004) and will most likely be extinct from mainland Europe with the climate warming expected over the next 50years. As these are natural unmanaged ecosystems there are no means of changing this development other than through acting towards reducing climate change in itself.

\subsection{Opportunities for $\mathrm{C}$ management in the fossil fuel/other anthropogenic sectors}

The main options for $\mathrm{CO}_{2}$ management in fossil-fuel use are avoidance and capture and storage. While the focus has been on avoiding emissions, e.g. through using energy more efficiently, substituting fuels with high $\mathrm{C}$ content by fuels with lower $\mathrm{C}$ content, and increased use of renewable energy sources like solar wind and biomass, there is increasing interest in capturing $\mathrm{CO}_{2}$ at the point of discharge and storing it somewhere away from the atmosphere. Replacement trends of solid and liquid fuels by natural gas, in particular in Europe, can have a considerable effect on the energy sector contribution to the $\mathrm{C}$ cycle (Table 4).

\section{Cross-sectoral issues and challenges}

A regional $\mathrm{C}$ budget is often a summation of sectoral $\mathrm{C}$ budgets, e.g. the energy sector, the agriculture sector, and the forestry sector are examples of such sectoral $\mathrm{C}$ budgets. However, none of the land use sectors can be seen in isolation. In the developing world, the spatial distinction between agriculture and forestry is often unclear. Lands may be used for crops for a couple of years and then left in fallow (secondary forests) for a few decades, while degraded forests may be used for grazing. In the developed world, where the spatial distinction is generally clearer, the sectors are still closely linked, and land use may change 


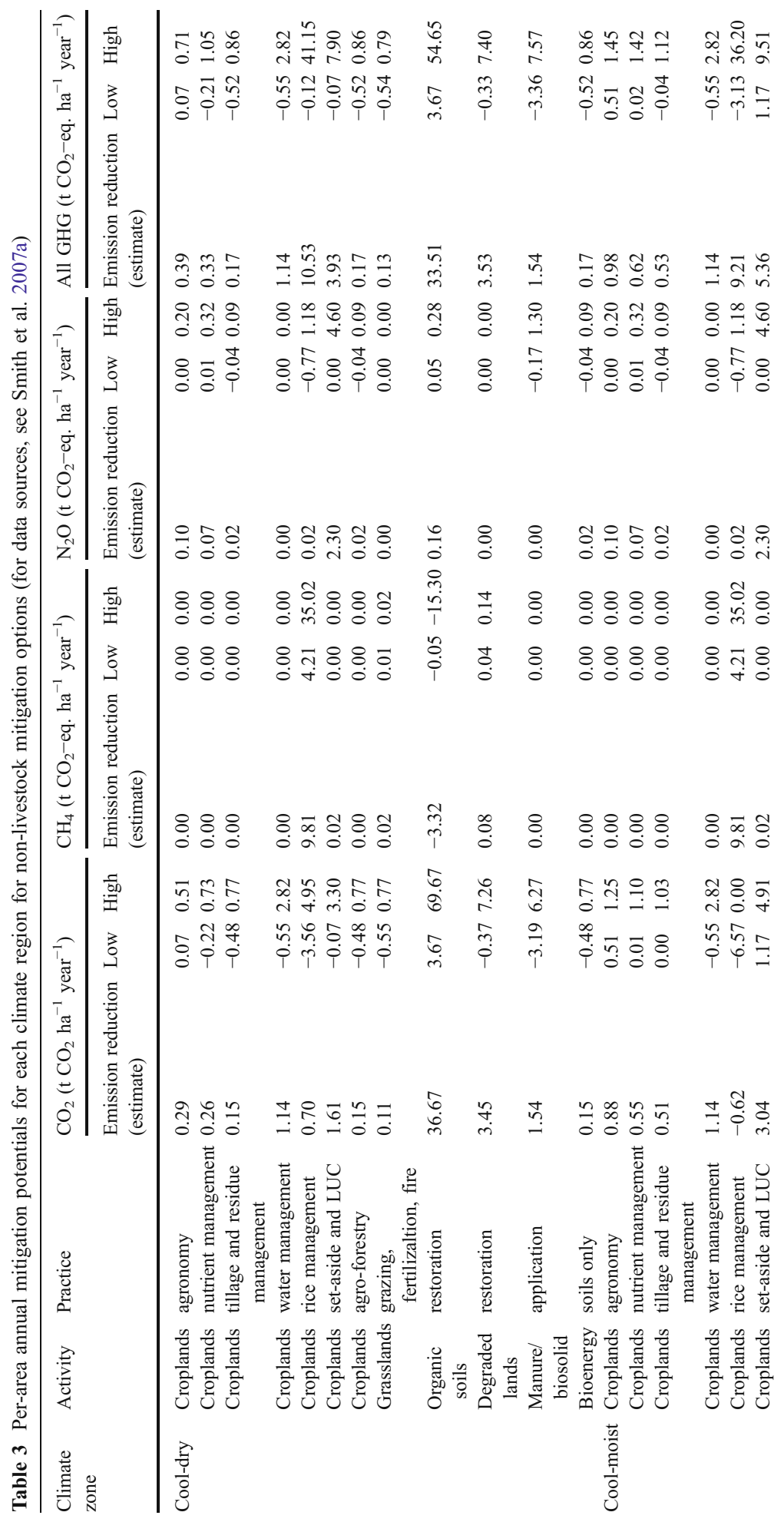




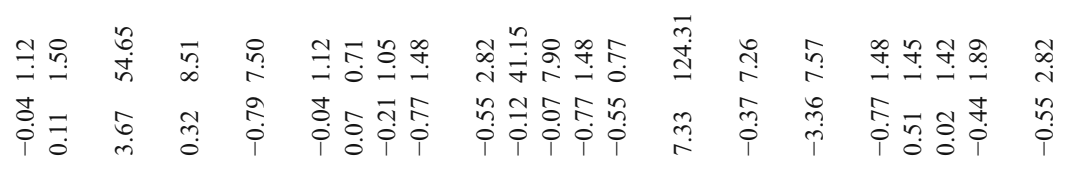

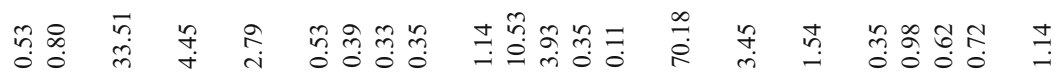

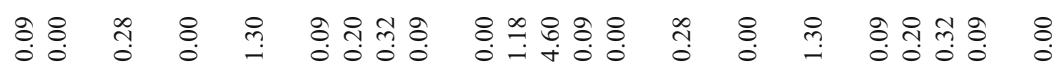



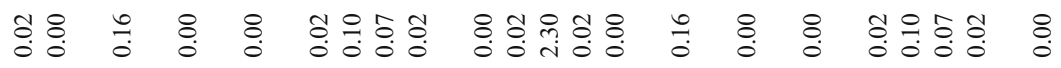

\&:

\&:

\&:

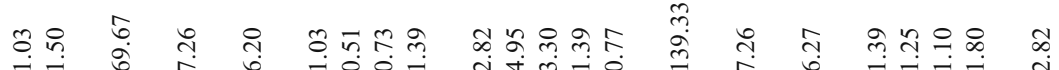

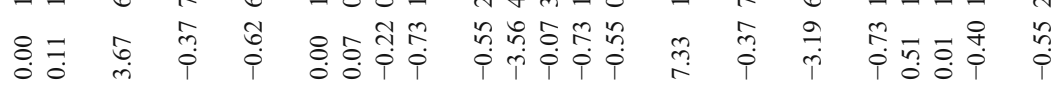

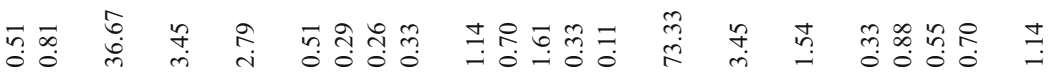

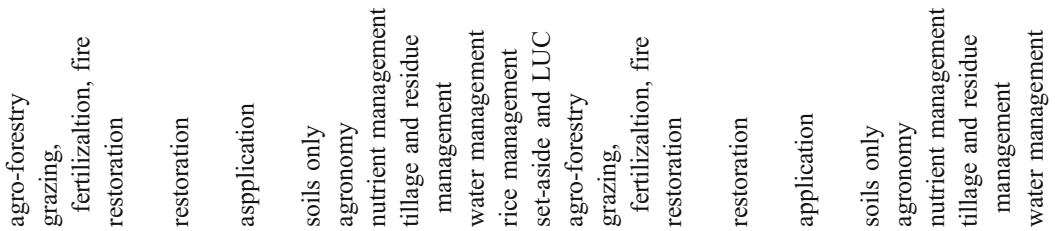

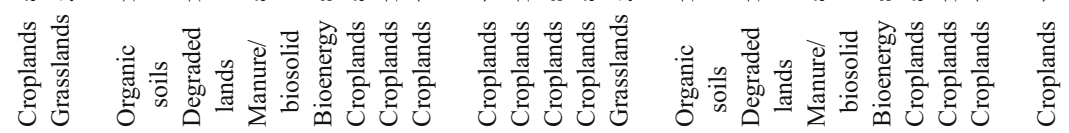

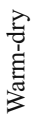




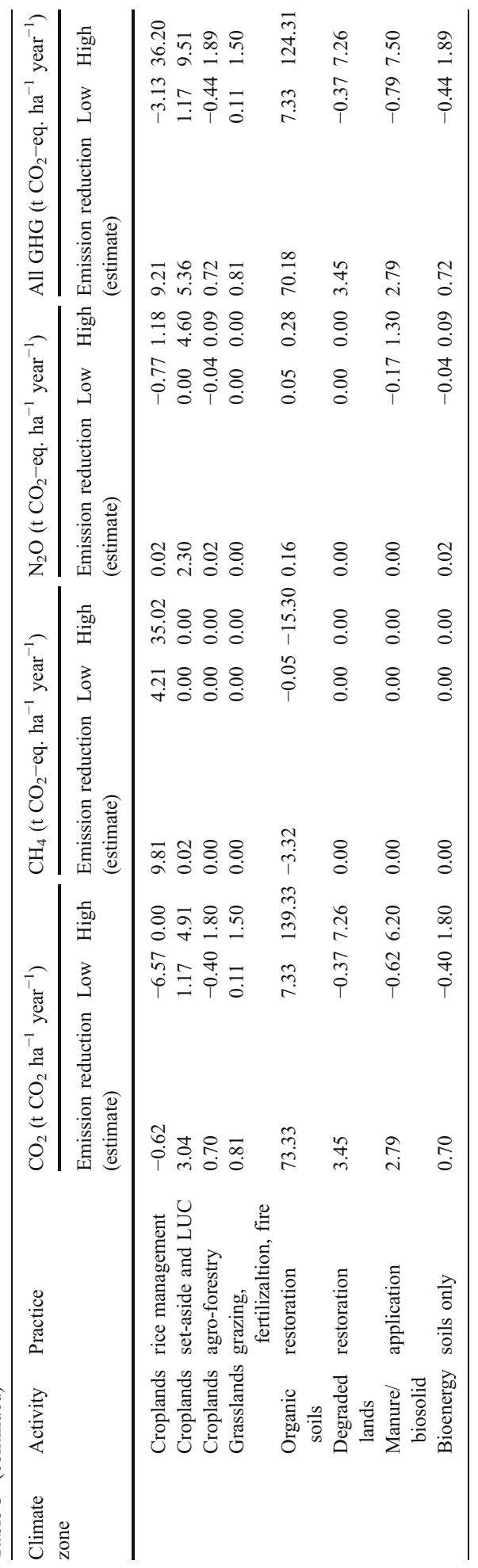

姐 Springer 
Table 4 Carbon content and fossil fuel carbon intensity of different fuels

\begin{tabular}{lll}
\hline Fuel & Carbon content $(\mathrm{kg}-\mathrm{C} / \mathrm{kg}$ fuel $)$ & Fossil fuel carbon intensity $(\mathrm{kg}-\mathrm{C} / \mathrm{MJ})$ \\
\hline Coal & 0.78 & 24.5 \\
Oil & 0.85 & 20.3 \\
Natural Gas & 0.76 & 13.8 \\
Wood & 0.45 & zero $^{\mathrm{a}}$ \\
\hline
\end{tabular}

a "Fossil" $\mathrm{C}$ intensity is the measure relevant to greenhouse gas, and by this measure wood from renewable harvest and re-growth of trees is zero in $\mathrm{C}$ intensity

in response to factors such as commodity prices and technological developments in agriculture. Global change drivers (e.g. population and GDP growth) have effects on multiple sectors. Integrated global models such as IMAGE (Strengers et al. 2004) can help to understand these interactions, but such large scale model lack the detailed information which a national policy maker (often a sectoral policy maker) might need. Therefore more detailed integrated models at the landscape scale or national scale are required. We have shown that for many reasons, it is useful to compile sectoral $\mathrm{C}$ budgets, but we must also recognised that these should not be used in isolation. There are some issues where cross sectoral analysis is necessary, as discussed below.

\subsection{Lateral transfers and leakage between sectors}

Sectoral $\mathrm{C}$ budgets reveal important $\mathrm{C}$ flows that either impact upon more than one sector or that are not accounted for in regional budgets (termed leakage). Examples of cross sector flows include fossil fuel use in agricultural or forestry operations, bioenergy crops and other biofuels transferred from the agricultural or forestry sectors to the energy sector and the use of agricultural and forestry products in other sectors (e.g. in urban development). Examples of sectoral flows that may be missed from regional budgets include the export of products (agricultural, forestry and fuel) between regions (Janssens et al. 2005). Whilst the mechanism to track fossil fuel transfers between regions is well developed, this is not the case for the exchange of agricultural and forest products between regions. Such imports of products (such as cattle feed) from outside a region can have profound effects on national $\mathrm{C}$ and greenhouse gas budgets in other areas (Janssens et al. 2005). Similarly, if C is captured (whether in trees or in geologic reservoirs), there is increased risk that this $\mathrm{C}$ will be released in some subsequent time period.

The transfer of electricity or energy-intensive products across sectoral or regional boundaries can mean that actions in one area are reflected in $\mathrm{CO}_{2}$ emissions elsewhere. West and Marland (2003) note that actions to sequester C in agricultural soils may, at the same time, impact the amount of fuel used in agricultural machinery, and the amount of fuel used to produce $\mathrm{N}$ and other fertilizers, as well as the energy used for insecticides, irrigation, product transport, etc. Schlamadinger and Marland (1999) have shown that the flow of $\mathrm{C}$ in forest products can have a major impact on the net $\mathrm{C}$ impact of forest management, and that it may be even more important to consider the issues of product substitution. Use of wood products in construction means that some alternate, perhaps energy-intensive material (perhaps steel, aluminium, concrete, or glass) is not being used.

Use of automotive gasoline is accompanied by discharge of $\mathrm{CO}_{2}$ to the atmosphere at the point of combustion, but it also implies that a total of 1.16 times that amount of $\mathrm{CO}_{2}$ has been emitted by the time we consider the exploration, production, transport, and refining of the fuel (West and Marland 2002). Ethanol fuel can be considered to have no net $\mathrm{CO}_{2}$ 
emissions if the ethanol is produced from corn or sugar cane, but significant amounts of fossil fuels are generally used for the agricultural and conversion processes (Kheshgi et al. 2000; Sims et al. 2006).

Sectoral budgets should also include loss of $\mathrm{C}$ to aquatic systems. Organic $\mathrm{C}$ lost by human activities is either stored in land reservoirs, processed and released as $\mathrm{CO}_{2}$, or exported to the ocean (Meybeck and Vörösmarty 2005, Mackenzie et al. 2004, Schlünz and Schneider 2000).

\subsection{Policies, trade-offs, synergies and unintended outcomes}

When considering policy impacts upon sectoral $\mathrm{C}$ budgets, their propagation beyond the target sector needs to be considered. For example policies to encourage afforestation, can impact upon both agricultural land and peatlands/ wetlands, or the encouragement of organic matter additions to agricultural soils, could deplete peat stocks if they are the dominant organic $\mathrm{C}$ source. Such cases illustrate trade-offs among sectors. There are policies, however, that encourage synergies between sectors. Examples include the limitation of fossil fuel use, which may provide more favourable markets for biofuels from the forestry and agricultural sectors, and the protection of natural areas, which may conserve land-use in traditional usage and benefit other land-based sectors. In addition to policies that have direct synergies or trade-offs between sectors, other policies may have unintended outcomes within, or outside, the sector. Policies to encourage biodiversity, for example, may result in large forest reserves. Whilst this outcome is largely beneficial, a reduction in availability of wood products could lead to increased use of fossil fuels for concrete and plastics. Other examples of unintended outcomes arise from displacement, for example when reducing deforestation in one region may result in increased deforestation in other, more sensitive regions.

\section{Conclusions}

This review has highlighted a number of research priorities for improving sectoral $\mathrm{C}$ budgets. These are (a) improving the coverage in data-poor regions which could be achieved by capacity building and training, (b) use of shared protocols and site networks such as CarboEurope, Chinaflux/Asiaflux, SOMNET, LBA etc., (c) the harmonisation of common methods, models and protocols across sectors to facilitate the comparability of scientific findings across regions and sectors, (d) a move to full $\mathrm{C}$ accounting to avoid leakage and double counting, (e) full greenhouse gas accounting so that the impact of management on the global warming potential can be assessed.

\section{References}

Aber JD, Driscoll CD (1997) Effects of land use, climate variation and N deposition on N cycling and C storage in northern hardwood forests. Glob Biogeochem Cycles 11:639-648

Alexeyev V, Birdsey R, Stakanov V, Korotkov I (1995) Carbon in vegetation of Russian forests - methods to estimate storage and geographical-distribution. Water Air Soil Pollut 82:271-282

Alvarez R (2001) Estimation of carbon losses by cultivation from soils of the Argentine Pampas using the Century model. Soil Use Manage 17:62-66

Andres RJ, Marland G, Fung I, Matthews E (1996) A $1^{\circ} \times 1^{\circ}$ distribution of carbon dioxide emissions from fossil fuel consumption and cement manufacture, 1950-1990'. Glob Biogeochem Cycles 10:419-429 
Aurela M, Laurila T, Tuovinen JP (2002) Annual CO2 balance of a subarctic fen in northern Europe: importance of the wintertime efflux. J Geophys Res Atmos 107:4607

Baldocchi DD (2003) Assessing the eddy covariance technique for evaluating carbon dioxide exchange rates of ecosystems: past, present and future. Glob Chang Biol 9:479-492

Balesdent J, Mariotti A, Guillet B (1987) Natural ${ }^{13} \mathrm{C}$ abundance as a tracer for studies of soil organic matter dynamics. Soil Biol Biochem 19:25-30

Battaglia M, Sands PJ (1998) Process-based forest productivity models and their applications in forest management. For Ecol Manage 102:13-32

Belyea LR, Baird AJ (2006) Beyond "the limits to peat bog growth": cross-scale feedback in peatland development. Ecol Monogr 76:299-322

Bhatia A, Pathak H, Aggarwal PK (2004) Inventory of methane and nitrous oxide emissions from agricultural soils of India and their global warming potential. Curr Sci 87(3):317-324

Bird SB, Herrick JE, Wander MM, Wright SF (2002) Spatial heterogeneity of aggregate stability and soil carbon in semi-arid rangeland. Environ Pollut 116:445-455

Blasing TJ, Broniak CT, Marland G (2005a) The annual cycle of fossil-fuel carbon dioxide emissions in the United States. Tellus, Ser B Chem Phys Meteorol 57:107-115

Blasing TJ, Broniak C, Marland G (2005b) State-by-state carbon dioxide emissions from fossil-fuel use in the United States 1960-2000. Mitig Adapt Strategies Glob Chang 10:659-674

Bossel H (1996) TREEDYN3 forest simulation model. Ecol Model 90:187-227

Bousquet P, Peylin P, Ciais P, Ramonet M, Monfray P (1999) Inverse modeling of annual atmospheric $\mathrm{CO}_{2}$ sources and sinks 2. Sensitivity study. J Geophys Res Atmos 104(D21):26179-26193

Cannell MGR, Milne R, Hargreaves KJ, Brown TAW, Cruickshank MM, Bradley RI, Spencer T, Hope D, Billett MF, Adger WN, Subak S (1999) National inventories of terrestrial carbon sources and sinks: the UK experience. Clim Change 42:505-530

Cao MK, Marshall S, Gregson K (1996) Global carbon exchange and methane emissions from natural wetlands: application of a process-based model. J Geophys Res Atmos 101(D9):14399-14414

CarboEurope-IP (2004) www.carboeurope.org

Chen JM, Liu J, Cihlar J, Goulden ML (1999) Daily canopy photosynthesis model through temporal and spatial scaling for remote sensing applications. Ecol Model 124:99-119

Chen WJ, Chen JM, Cihlar J (2000) Integrated terrestrial ecosystem carbon-budget model based on changes in disturbance, climate, and atmospheric chemistry. Ecol Model 135:55-79

Chevallier T, Voltz M, Blanchart E, Chotte JL, Eschenbrenner V, Mahieu M, Albrecht A (2000) Spatial and temporal changes of soil $\mathrm{C}$ after establishment of a pasture on a long-term cultivated vertisol (Martinique). Geoderma 94:43-58

Christensen TR, Friborg T (eds) (2004) EU peatlands: current carbon stocks and trace gas fluxes. European Commission, CarboEurope-GHG Report 7. Specific Study 4

Christensen TR, Prentice IC, Kaplan J, Haxeltine A, Sitch S (1996) Methane flux from northern wetlands and tundra: an ecosystem source modelling approach. Tellus 48B:651-660

Christensen TR, Johansson T, Malmer N, Åkerman J, Friborg T, Crill P, Mastepanov M, Svensson B (2004) Thawing sub-arctic permafrost: Effects on vegetation and methane emissions. Geophys Res Lett 31: L04501, http://dx.doi.org/10.1029/2003GL018680

Ciais P, Tans PP, Trolier M, White JWC, Francey RJ (1995) A large northern-hemisphere terrestrial $\mathrm{CO}_{2}$ sink indicated by the $\mathrm{C}^{-13} / \mathrm{C}^{-12}$ ratio of atmospheric $\mathrm{CO}_{2}$. Science $269: 1098-1102$

Ciccioli P, Brancaleoni E, Frattoni M, Di Palo V, Valentini R, Tirone G, Seufert G, Bertin N, Hansen U, Csiky O, Lenz R, Sharma M (1999) Emission of reactive terpene compounds from orange orchards and their removal by within-canopy processes. J Geophys Res Atmos 104:8077-8094

Clymo RS (1984) The limits to peat bog growth. Philos Trans R Soc Lond B 303:605-654

Cole V et al (1996) Agricultural options for mitigation of greenhouse gas emissions. In: Watson RT, Zinyowera MC, Moss RH, Dokken DJ (eds) Climate Change 1995. Impacts, adaptations and mitigation of climate change: scientific-technical analyses. Cambridge University Press, New York, pp 745-771

Conant RT, Paustian K, Elliott ET (2001) Grassland management and conversion into grassland: effects on soil carbon. Ecol Appl 11:343-355

Corradi C, Kolle O, Walter K, Zimov SA, Schulze ED (2005) Carbon dioxide and methane exchange of a north-eat Siberian tussock tundra. Glob Chang Biol 11:1910-1925

CTIC (2006) Conservation Technology Information Center. http://www.ctic.purdue.edu/CTIC/BuffersProject/ index.html

de Moraes JFL, Volkoff B, Cerri CC, Bernoux M (1996) Soil properties under Amazon forest and changes due to pasture installation in Rondônia, Brazil. Geoderma 70:63-81

de Pury DGG, Farquhar GD (1997) Simple scaling of photosynthesis from leaves to canopies without the errors of big-leaf models. Plant Cell Environ 20:537-557 
Del Galdo I, Six J, Peressotti A, Cotrufo MF (2003) Assessing the impact of land use change on soil C sequestration in agricultural soils by means of organic matter fractionation and stable $\mathrm{C}$ isotopes. Glob Chang Biol 9:1204-1213

Ewert F, Rounsevell MDA, Reginster I, Metzger M, Leemans R (2005) Future scenarios of European agricultural land use. I: estimating changes in crop productivity. Agric Ecosyst Environ 107:101-116

Fang JY, Chen AP, Peng CH, Zhao SQ, Ci L (2001) Changes in forest biomass carbon storage in China between 1949 and 1998. Science 292:2320-2322

Fang JY, Piao S, Field C, Pan Y, Tang Z, Guo Q, Zhou LM, Peng C, Tao S (2003) Increasing net primary production in China from 1982 to 1999. Front Ecol Environ 1:293-297

Felzer B, Kicklighter DW, Melillo JM, Wang C, Zhuang Q, Prinn R (2004) Effects of ozone on net primary production and carbon sequestration in the conterminous United States using a biogeochemistry model. Tellus 56B:230-248

Follett RF (2001) Organic carbon pools in grazing land soils. In: Follett RF, Kimble JM, Lal R (eds) The potential of U.S. grazing lands to sequester carbon and mitigate the greenhouse effect. Lewis Publishers, Boca Raton, pp 65-86

Follett RF, Schuman GE (2005) Grazing land contributions to carbon sequestration. In: McGilloway DA (ed) Grassland: a global resource. Wageningen Academic Publishers, The Netherlands, pp 265-277

Franzluebbers AJ, Stuedemann JA, Schomberg HH (2000) Spatial distribution of soil carbon and nitrogen pools under grazed tall fescue. Soil Sci Soc Am J 64:635-639

Freibauer A, Rounsevell M, Smith P, Verhagen A (2004) Carbon sequestration in the agricultural soils of Europe. Geoderma 122:1-23

Friborg T, Soegaard H, Christensen TR, Lloyd CR, Panikov NS (2003) Siberian wetlands: where a sink is a source. Geophys Res Lett 30(21):2129

Frolking S, Roulet NT, Moore TR, Richard PJH, Lavoie M (2001) Modeling northern peatland decomposition and peat accumulation. Ecosystems 4:479-498

Garcia SC, Holmes CW (2005) Seasonality of calving in pasture-based dairy systems: its effects on herbage production, utilisation and dry matter intake. Aust J Exp Agric 45:1-9

Gluck M, Banko G, Vrzal W (eds) (2000) Harnessing remote sensing to accomplish full carbon accounting: Workshop report, interim Report IR-00-010. International Institute for Applied Systems Analysis, Austria

Goodale C, Apps MJ, Birdsey RA, Field CB, Heath LS, Houghton RA, Jenkins JC, Kohlmaier GH, Kurz W, Liu S, Nabuurs G-J, Nilsson S, Shvidenko AZ (2002) Forest carbon sinks in the northern hemisphere. Ecol Appl 12:891-899

Gorham E (1991) Northern peatlands: role in the carbon cycle and probable responses to climatic warming. Ecol Appl 1:182-195

Gregg JS (2005) Improving the temporal and spatial resolution of carbon dioxide emissions from fossil-fuel consumption. A thesis submitted to the graduate faculty of the University of North Dakota, August, 2005, 404 pp (data available at http://cdiac.esd.ornl.gov.)

Hadi A, Inubushi K, Razie F, Purnomo E, Yusran FH, Tsuruta H (2000) Dynamics of methane and nitrous oxide in the tropical peatlands. In: Murdiyarso D, Tsuruta H (eds) The impacts of land-use/cover change on greenhouse gas emission in tropical Asia. ICSEA/GCTE/NIES, Bogor

Hadi A, Inubushi K, Furukawa Y, Purnomo E, Rasmadi M, Tsuruta H (2005) Greenhouse gas emissions from tropical peatlands of Kalimantan, Indonesia. Nutr Cycl Agroecosyst 71:73-80

Hahn V, Buchmann N (2004) A new model for soil organic carbon turnover using bomb carbon. Glob Biogeochem Cycles 18(1), Art. No. GB1019

Hicke JA, Lobell DB, Asner GP (2004) Cropland area and net primary production computed from 30years of USDA agricultural harvest data. Earth Interact 8:1-20

Huang Y, Zhang W, Zheng XH, Li J, Yu YQ (2004a) Modeling methane emission from rice paddies with various agricultural practices. J Geophys Res 109:D08113

Huang Y, Zhang W, Zheng XH, Wang YS (2004b) Carbon fixation in Chinese croplands from 1950 to 1999 and key factors. In: Proc. on carbon cycling and carbon management in China (in Chinese), Beijing, 12th-14th November 2004. pp 85-86

Husein YA, Murdiyarso D, Khalil MAK, Rasmussen RA, Shearer MJ, Sabiham S, Sunar A, Adijuwana A (1995) Methane flux from Indonesian wetland rice: the effects of water management and rice variety. Chemosphere 31:3153-3180

IPCC (1997) Revised 1996 IPCC guidelines for national greenhouse gas inventories. Meteorological Office, Bracknell, UK

IPCC (2000) Special report on land use, land-use change and forestry. Cambridge University Press, Cambridge 
IPCC (2003) Good practice guidance for land use, land-use change and forestry (GPG-LULUCF). Institute for Global Environmental Strategies (IGES) for the IPCC, Kanagawa, Japan

Isaev A, Korovin G, Zamolodchikov D, Utkin A, Pryaznikov A (1995) Carbon stock and deposition in phytomass of the Russian forests. Water Air Soil Pollut 82:247-256

Janssens IA, Freibauer A, Ciais P, Smith P, Nabuurs G-J, Folberth G, Schlamadinger B, Hutjes RWA, Ceulemans R, Schulze E-D, Valentini R, Dolman H (2003) Carbon sinks and sources in the European terrestrial biosphere. Science 300:1538-1542

Janssens IA, Freibauer A, Schlamadinger B, Ceulemans R, Ciais P, Dolman AJ, Heimann M, Nabuurs G-J, Smith P, Valentini R, Schulze ED (2005) The carbon budget of terrestrial ecosystems at country-scale. A European case study. Biogeosciences 2:15-27

Jenkinson DS (1988) Soil organic matter and its dynamics. In: Wild A (ed) Russell's soil conditions and plant growth. 11th edn. Longman, London, pp 564-607

Jenkinson DS, Coleman K (1994) Calculating the annual input of organic-matter to soil from measurements of total organic-carbon and radiocarbon. Eur J Soil Sci 45:167-174

Jones RJA, Hiederer R, Rusco E, Loveland PJ, Montanarella L (2003) Topsoil organic carbon in Europe. In: Proc. 4th European Congress on Regional Geoscientific Cartography and Information Systems, Bologna, 17th -20th June 2003. pp 249-251

Jones RJA, Hiederer R, Rusco E, Loveland PJ, Montanarella L (2004) The map of organic carbon in topsoils in Europe, Version 1.2 September 2003: explanation of Special Publication Ispra 2004 No.72 (S.P. I.04.72). European Soil Bureau Research Report No.17, EUR 21209 EN. Office for Official Publications of the European Communities, Luxembourg, 26pp. and 1 map in ISO B1 format

Karjalainen T, Pussinen A, Liski J, Nabuurs GJ, Eggers T, Lapvetelainen T, Kaipainen T (2003) Scenario analyses of the impacts of forest management and climate change on the European forest sector carbon budget. Forest Policy and Economics 5:141-155

Kauppi P, Kari M, Kuusela K (1992) Biomass and carbon budget of European forests, 1971 to 1990. Science 256:70-79

Kesselmeier J, Ciccioli P, Kuhn U, Stefani P, Biesenthal T, Rottenberger S, Wolf A, Vitullo M, Valentini R, Nobre A, Kabat P, Andreae MO (2002) Volatile organic compound emissions in relation to plant carbon fixation and the terrestrial carbon budget. Glob Biogeochem Cycles 16:1126

Kheshgi HS, Prince RC, Marland G (2000) The potential of biomass fuels in the context of global climate change: focus on transportation fuels. Annu Rev Energy Environ 25:199-244

Kimmins JP, Mailly D, Seely B (1999) Modelling forest ecosystem net primary production: the hybrid simulation approach used in FORECAST. Ecol Model 122:195-224

Kruijt B, Elbers JA, von Randow C, Araujo AC, Oliveira PJ, Culf A, Manzi AO, Nobre AD, Kabat P, Moors EJ (2004) The robustness of eddy correlation fluxes for Amazon rain forest conditions. Ecol Appl 14: S101-S113

Kurz WA, Apps MJ (1999) A 70-year retrospective analysis of carbon fluxes in the Canadian forest sector. Ecol Appl 9:526-547

Lafleur PM, Roulet NT, Bubier JL, Frolking S, Moore TR (2003) Interannual variability in the peatlandatmosphere carbon dioxide exchange at an ombrotrophic bog. Glob Biogeochem Cycles 17:1036

Lal R (2004) Soil carbon sequestration to mitigate climate change. Geoderma 123:1-22

Landsberg JJ (1986) Physiological ecology of forest production. Academic Press, Sydney, Australia

Landsberg JJ, Waring RH (1997) A generalised model of forest productivity using simplified concepts of radiation-use efficiency, carbon balance and partitioning. For Ecol Manage 95:209-228

Lappalainen E (ed) (1996) Global peat resources. International Peat Society and Geological Survey of Finland, pp 57-162

Li C, Frolking S, Butterbach-Bahl K (2005) Carbon sequestration in arable soils is likely to increase nitrous oxide emissions offsetting reductions in climate radiative forcing. Clim Change 72:321-338

Liu JX, Peng CH, Apps MJ, Dang QL, Banfield E, Kurz W (2002) Historic carbon budget of Ontario's forest ecosystems. For Ecol Manag 169:103-114

Lobell DB, Hicke JA, Asner GP, Field CB, Tucker CJ, Los SO (2002) Satellite estimates of productivity and light use efficiency in United States agriculture, 1982-98. Glob Chang Biol 8:722-735

Lobell DB, Asner GP, Ortiz-Monasterio JI, Benning TL (2003) Remote sensing of regional crop production in the Yaqui Valley, Mexico: estimates and uncertainties. Agric Ecosyst Environ 94:205-220

Losey LM (2004) Monthly and seasonal estimates of carbon dioxide emissions fro fossil fuel consumption in Canada, Mexico, The United Kingdon, France, Spain, Italy, and Poland. A thesis submitted to the graduate faculty of the University of North Dakota, May, 2004, 328 pp (data available at http://cdiac.esd.ornl.gov.)

Luoto M, Heikkinen R, Carter T (2004) Loss of palsa mires in Europe and biological consequences. Environ Conserv 31(1):30-37 
Mackenzie FT, Lerman A, Andersson AJ (2004) Past and present of sediment and carbon biogeochemical cycling models. Biogeosciences 1:11-32

Malmer N, Johansson T, Olsrud M, Christensen TR (2005) Vegetation, climatic changes and net carbon sequestration. Glob Chang Biol 11:1895-1909

Maltby E, Immirizi CP (1993) Carbon dynamics in peatlands and other wetlands soils: regional and global perspective. Chemosphere 27:999-1023

Marland G, Brenkert A, Olivier J (1999) $\mathrm{CO}_{2}$ from fossil fuel burning: a comparison of ORNL and EDGAR estimates of national emissions. Environ Sci Policy 2:265-273

Martin P (1998) Estimating the $\mathrm{CO}_{2}$ uptake in Europe. Science 281:1806-1806

McConkey BG, Brierley JA, VandenBygaart A, Huffman T, Martin T, Bentham M, Desjardins RL, Monreal CM, Patterson CT, Rochette P, Liang BC, Smith WN, de Grooijer H, Gameda S, Boehm M (2008) Estimating carbon change for Canada with the National Carbon and Greenhouse-Gas emission Accounting and Verification System for agriculture (NCGAVS). Can J Soil Sci, (in press)

McGuire AD, Melillo JM, Kicklighter DW, Pan Y, Xiao X, Helfrich J, Moore B III, Vorosmarty CJ, Schloss AL (1997) Equilibrium responses of global net primary production and carbon storage to doubled atmospheric carbon dioxide: sensitivity to changes in vegetation nitrogen concentration. Glob Biogeochem Cycles 11:173-189

Medlyn BE, McMurtrie RE, Dewar RC, Jeffreys MP (2000) Soil processes dominate the long-term response of forest net primary productivity to increased temperature and atmospheric $\mathrm{CO}_{2}$ concentration. Can $\mathrm{J}$ For Res 30:873-888

Meybeck M, Vörösmarty C (2005) Fluvial filtering of land-to-ocean fluxes: from natural Holocene variations to Anthropocene. Comptes Rendus Geoscience 337:107-123

Mitchell TD, Carter TR, Jones PD, Hulme M, New M (2004) A comprehensive set of high-resolution grids of monthly climate for Europe and the globe: the observed record (1901-2000) and 16 scenarios (20012100). Working Paper 55, Tyndall Centre for Climate Change Research, University of East Anglia, Norwich

Morales P, Sykes MT, Prentice IC, Smith P, Smith B, Bugmann H, Zierl B, Friedlingstein P, Viovy N, Sabaté S, Sánchez A, Pla E, Gracia CA, Sitch S, Arneth A, Ogee J (2005) Comparing and evaluating process-based ecosystem model predictions of carbon and water fluxes in major European forest biomes. Glob Chang Biol 11:2211-2233

Murdiyarso D, Adiningsih ES (2008) Climatic variability, Indonesian vegetation fires and terrestrial carbon emissions. J Mitigation and Adaptation Strategies for Global Change, (in press)

Nabuurs GJ, Paivinen R, Sikkema R, Mohren GMJ (1997) The role of European forests in the global carbon cycle - A review. Biomass Bioenergy 13(6):345-358

Nabuurs GJ, Pussinen A, Karjalainen T, Ehrhard M, Kramer K (2002) Stemwood volume increment changes in European forests due to climate change; a simulation study with the EFISCEN model. Glob Chang Biol 8:304-316

NCAS (2002) Greenhouse gas emissions from land use change in Australia: an integrated application of the National Carbon Accounting System. Australian Greenhouse Office, Canberra, ACT, p 124

Neuzil SG (1997) Onset and rate of peat and carbon accumulation in four domed ombrogenous peat deposits in Indonesia. In: Rieley JO, Page SE (eds) Biodiversity and sustainability of tropical peatlands. Samara Publishing Ltd, Cardigan, pp 55-72

Ni J (2002) Carbon storage in grasslands of China. J Arid Environ 50:205-218

Ni J (2004a) Estimating grassland net primary productivity from field biomass measurements in temperate northern China. Plant Ecol 174:217-234

Ni J (2004b) Forage yield-based carbon storage in grasslands of China. Clim Change 67:237-246

Nishimura S, Sawamoto T, Akiyama H, Sudo S, Yagi K (2004) Methane and nitrous oxide emissions from a paddy field with Japanese conventional water management and fertilizer application. Glob Biogeochem Cycles 18:GB2017

Nobre AD, Harriss RC (2002) Saving the rainforest with sustainable enterprises in degraded lands: the Amazonian phoenix project. In: Proceeding of Working Forests in the Tropics Conference, Gainesville, Fl, USA, February, 2002

Nordstroem C, Soegaard H, Christensen TR, Friborg T, Hansen BU (2001) Seasonal carbon dioxide balance and respiration of a high- arctic fen ecosystem in NE-Greenland. Theor Appl Climatol 70:149-166

Oechel WC, Vourlitis GL, Hastings SJ, Zulueta RC, Hinzman L, Kane D (2000) Acclimation of ecosystem $\mathrm{CO}_{2}$ exchange in the Alaskan Arctic in response to decadal climate warming. Nature 406:978-981

Ogle SM, Breidt FJ, Paustian K (2005) Agricultural management impacts on soil organic carbon storage under moist and dry climatic conditions of temperate and tropical regions. Biogeochemistry 72:87121 
Olivier JGJ, Berdowski JJM (2001) Global emissions sources and sinks. In: Berdowski J, Guicherit R, Heij BJ (eds) The climate system. A.A. Balkema Publishers/Swets \& Zeitlinger Publishers, Lisse, The Netherlands, pp 33-78

Ollinger SV, Aber JD, Reich PB, Freuder RJ (2002) Interactive effects of nitrogen deposition, tropospheric ozone, elevated $\mathrm{CO}_{2}$ land use history on the carbon dynamics of northern hardwood forests. Glob Chang Biol 8:545-562

Page SE, Siegert F, Rieley JO, Boehm HD, Jaya A (2002) The amount of carbon released from peat and forest fires in Indonesia during 1997. Nature 420:61-65

Païvinen R, Anttila P (2001) How reliable is a satellite forest inventory? Silva Fenn 35:125-127

Pan Y, Hom J, Birdsey R, McCullough K (2004) Impacts of rising nitrogen deposition on N exports from forests to surface waters in the Chesapeake Bay watershed. Environmental Management 33(4):s120s131

Pan Y, Hom J, Birdsey R, McCullough K (2008) Multiple stressors and carbon dynamics in Atlantic temperate forests. Ecosystems (in press)

Papale D, Valentini R (2003) A new assessment of European forests carbon exchanges by eddy fluxes and artificial neural network spatialization. Glob Chang Biol 9:525-535

Parton WJ, Scurlock JM, Ojima DS, Gilmanov TG, Scholes RJ, Schimel DS, Kirchner T, Menaut J-C, Seastedt T, Garcia Moya E, Kamnalrut A, Kinyamario JI (1993) Observations and modelling of biomass and soil organic matter dynamics for the grassland biome worldwide. Glob Biogeochem Cycles 7:785-809

Parton WJ, Gutmann MP, Williams SA, Easter M, Ojima D (2005) Ecological impact of historical land-use patterns in the great plains: a methodological assessment. Ecol Appl 15:1915-1928

Pastor J, Post WM (1988) Response of northern forests to $\mathrm{CO}_{2}$-induced climate change. Nature 334:55-58

Paustian K, Cole CV, Sauerbeck D, Sampson N (1998) $\mathrm{CO}_{2}$ mitigation by agriculture: an overview. Clim Change 40:135-162

Peng CH (2000) Understanding the role of forest simulation models in sustainable forest management. Environ Impact Assess Rev 20:481-501

Peng CH, Liu JX, Dang QL, Apps MJ, Jiang H (2002) TRIPLEX: a generic hybrid model for predicting forest growth and carbon and nitrogen dynamics. Ecol Model 153:109-130

Phillips OL, Malhi Y, Higuchi N, Laurance WF, Nunez PV, Vasquez RM, Laurance SG, Ferreira LV, Stern M, Brown S, Grace J (1998) Changes in the carbon balance of tropical forests: evidence from long term plots. Science 282:439-442

Piao SL, Fang JY, Zhou L, Tan K (2007) Changes in biomass carbon stocks in China's grasslands between 1982 to 1999. Glob Biogeochem Cycles 22, Art. No. GB2002 APR 112007

Potter C, Klooster S, Nemani R, Genovese V, Hiatt S, Fladeland M, Gross P (2006) Estimating carbon budgets for U.S. ecosystems. Eos Trans AGU 87(8):85

Ramankutty N, Foley JA (1999) Estimating historical changes in global land cover: croplands from 1700 to 1992. Glob Biogeochem Cycles 13:997-1027

Rangel-Castro JI, Prosser JI, Scrimgeour CM, Smith P, Ostle N, Ineson P, Meharg AA, Killham K (2004) Carbon flow in an upland grassland: effect of liming on the flux of recently photosynthesised carbon to rhizosphere soil. Glob Chang Biol 10:2100-2108.

Roberts DA, Keller M, Soares JV (2003) Studies of land-cover, land-use, and biophysical properties of vegetation in the large scale biosphere atmosphere experiment in Amazônia. Remote Sens Environ $87: 377-388$

Robertson GP (2004) Abatement of nitrous oxide, methane and other non-CO2 greenhouse gases: the need for a systems approach. In: Field CB, Raupach MR (eds) The global carbon cycle. Integrating humans, climate, and the natural world, Scope 62. Island Press, Washington DC, pp 493-506

Robertson GP, Paul EA, Harwood RR (2000) Greenhouse gases in intensive agriculture: contributions of individual gases to the radiative forcing of the atmosphere. Science 289:1922-1925

Robles MD, Burke IC (1998) Soil organic matter recovery on conservation reserve program fields in southeastern Wyoming. Soil Sci Soc Am J 62:725-730

Rojstaczer S, Sterling SM, Moore NJ (2001) Human appropriation of photosynthesis products. Science 294:2549-2552

Roulet NT (2000) Peatlands, carbon storage, greenhouse gases and the Kyoto Protocol: prospects and significance for Canada. Wetlands 20:605-615

Rounsevell MDA, Ewert F, Reginster I, Leemans R, Carter TR (2005) Future scenarios of European agricultural land use. II: estimating changes in land use and regional allocation. Agric Ecosyst Environ 107:117-135

Running SW, Nemani RR, Heinsch FA, Zhao M, Reeves M, Hashimoto H (2004) A continuous satellitederived measure of global terrestrial primary production. BioScience 54:547-560 
Saggar S, Andrew RM, Tate KR, Hedley CB, Rodda NJ, Townsend JA (2004) Modelling nitrous oxide emissions from dairy-grazed pastures. Nutr Cycl Agroecosyst 68:243-255

Saleska SR, Miller SD, Matross DM, Goulden ML, Wofsy SC, da Rocha HR, de Camargo PB, Crill P, Daube BC, de Freitas HC, Hutyra L, Keller M, Kirchhoff V, Menton M, Munger JW, Pyle EH, Rice AH, Silva H (2003) Carbon in amazon forests: unexpected seasonal fluxes and disturbance-induced losses. Science 302:1554-1557

Schlamadinger B, Marland G (1999) Net effect of forest harvest on $\mathrm{CO}_{2}$ emissions to the atmosphere: a sensitivity analysis on the influence of time. Tellus, Ser B Chem Phys Meteorol 51:314-325

Schlünz B, Schneider RR (2000) Transport of terrestrial organic carbon to the oceans by rivers: re-estimating flux- and burial rates. Int J Earth Sci 88:599-606

Schroeder P, Winjum J (1995) Assessing Brazil's carbon budget: I. Biotic carbon pools. For Ecol Manag 75:77-86

Sheeder SA, Lynch JA, Crimm J (2002) Modeling atmospheric nitrogen deposition and transport in the Chesapeake Bay watershed. J Environ Qual 31:1194-1206

Shvidenko A, Venevsky S, Raile G, Nilsson S (1995) A system for evaluation of growth and mortality in Russian forests. Water Air Soil Pollut 82:333-348

Sims REH, Hastings A, Schlamadinger B, Taylor G, Smith P (2006) Energy crops: current status and future prospects. Glob Chang Biol 12:2054-2076

Six J, Carpentier A, van Kessel C, Merckx R, Harris D, Horwath WR, Luscher A (2001) Impact of elevated $\mathrm{CO}_{2}$ on soil organic matter dynamics as related to changes in aggregate turnover and residue quality. Plant Soil 234:27-36

Six J, Ogle SM, Breidt FJ, Conant RT, Mosier AR, Paustian K (2004) The potential to mitigate global warming with no-tillage management is only realized when practiced in the long term. Glob Chang Biol $10: 155-160$

Smith P (2004a) CarboEurope GHG: greenhouse gas emissions from European croplands. CarboEurope GHG, University of Tuscia, Viterbo, Italy

Smith P (2004b) Carbon sequestration in croplands: the potential in Europe and the global context. Eur J Agron 20:229-236

Smith P (2004c) Soils as carbon sinks - the global context. Soil Use Manage 20:212-218

Smith P (2005) The permanence of soil organic carbon stocks: influence of direct human-induced, indirect and natural effects. Eur J Soil Sci 56:673-680

Smith P, Smith JU, Powlson DS, McGill WB, Arah JRM, Chertov OG, Coleman K, Franko U, Frolking S, Jenkinson DS, Jensen LS, Kelly RH, Klein-Gunnewiek H, Komarov A, Li C, Molina JAE, Mueller T, Parton WJ, Thornley JHM, Whitmore AP (1997a) A comparison of the performance of nine soil organic matter models using seven long-term experimental datasets. Geoderma 81:153-225

Smith P, Powlson DS, Glendining MJ, Smith JU (1997b) Potential for carbon sequestration in European soils: preliminary estimates for five scenarios using results from long-term experiments. Glob Chang Biol 3:67-79

Smith P, Powlson DS, Glendining MJ, Smith JU (1998) Preliminary estimates of the potential for carbon mitigation in European soils through no-till farming. Glob Chang Biol 4:679-685

Smith P, Powlson DS, Smith JU, Falloon PD, Coleman K (2000) Meeting Europe's climate change commitments: quantitative estimates of the potential for carbon mitigation by agriculture. Glob Chang Biol 6:525-539

Smith P, Falloon P, Smith JU, Powlson DS (eds) (2001a) Soil organic matter network (SOMNET): 2001 Model and Experimental Metadata. GCTE Report 7, 2nd edn. GCTE Focus 3 Office, Wallingford, Oxon, 224pp

Smith P, Goulding KW, Smith KA, Powlson DS, Smith JU, Falloon PD, Coleman K (2001b) Enhancing the carbon sink in European agricultural soils: including trace gas fluxes in estimates of carbon mitigation potential. Nutr Cycl Agroecosyst 60:237-252

Smith JU, Smith P, Monaghan R, Macdonald RJ (2002a) When is a measured soil organic matter fraction equivalent to a model pool? Eur J Soil Sci 53:405-416

Smith P, Falloon PD, Körschens M, Shevtsova LK, Franko U, Romanenkov V, Coleman K, Rodionova V, Smith JU, Schramm G (2002b) EuroSOMNET - a European database of long-term experiments on soil organic matter: the WWW metadatabase. Journal of Agricultural Science Cambridge 138:123-134

Smith JU, Smith P, Wattenbach M, Zaehle S, Hiederer R, Jones RJA, Montanarella L, Rounsevell M, Reginster I, Ewert F (2005) Projected changes in mineral soil carbon of European croplands and grasslands, 1990-2080. Glob Chang Biol 11:2141-2152

Smith P, Martino D, Cai Z, Gwary D, Janzen HH, Kumar P, McCarl B, Ogle S, O’Mara F, Rice C, Scholes RJ, Sirotenko O, Howden M, McAllister T, Pan G, Romanenkov V, Schneider U, Towprayoon S, Wattenbach M, Smith JU (2007a) Greenhouse gas mitigation in agriculture. Philos Trans R Soc Lond, B 363, http://dx.doi.org/10.1098/rstb.2007.2184 
Smith P, Martino D, Cai Z, Gwary D, Janzen HH, Kumar P, McCarl B, Ogle S, O’Mara F, Rice C, Scholes RJ, Sirotenko O, Howden M, McAllister T, Pan G, Romanenkov V, Schneider U, Towprayoon S (2007b) Influence of climate and non-climate policy on implementation of agricultural greenhouse gas mitigation options. Agric Ecosyst Environ 118:6-28

Sorensen KW (1993) Indonesian peat swamp forests and their role as a carbon sink. Chemosphere 27:1065-1082

Soussana JF, Loiseau P, Vuichard N, Ceschia E, Balesdent J, Chevallier T, Arrouays D (2004) Carbon cycling and sequestration opportunities in temperate grasslands. Soil Use Manage 20:219-230

Strengers B, Leemans R, Eickhout B, ve Vries B, Bouwman L (2004) The land-use projections and resulting emissions in the IPCC SRES scenarios as simulated by the IMAGE 2.2 model. GeoJournal 61:381-393

Suratno W, Murdiyarso D, Suratmo FG, Anas I, Saeni MS, Rambe A (1998) Nitrous oxide emission from irrigated rice fields in West Java. J Environ Pollution 102:159-166

Tacconi L (2003) Fires in Indonesia: causes, costs and policy implications. CIFOR Occasional Paper No. 38

Tate KR, Scott NA, Parshotam A, Brown L, Wilde RH, Giltrap DJ, Trustrum NA, Gomez B, Ross DJ (2000) A multi-scale analysis of a terrestrial carbon budget - is New Zealand a source or sink of carbon? Agric Ecosys Env 82:229-246

Thornton PE, Running SW, White MA (1997) Generating surfaces of daily meteorological variables over large regions of complex terrain. J Hydrol 190:214-251

Turner DP, Koerper GJ, Harmon ME, Lee JJ (1995) A carbon budget for forests of the conterminous United States. Ecol Appl 5:421-436

Turunen J, Tahvanainen T, Tolonen K, Pitkanen A (2001) Carbon accumulation in West Siberian mires, Russia. Glob Biogeochem Cycles 15:285-296

UN-ECE/FAO (2000) Forest products annual market review 1999-2000. http://www.unece.org/trade/timber/ docs/rev-00/rev00.htm

Valentini R, Matteucci G, Dolman AJ, Schulze ED, Rebmann C, Moors EJ, Granier A, Gross P, Jensen NO, Pilegaard K, Lindroth A, Grelle A, Bernhofer C, Grunwald T, Aubinet M, Ceulemans R, Kowalski AS, Vesala T, Rannik U, Berbigier P, Loustau D, Guomundsson J, Thorgeirsson H, Ibrom A, Morgenstern K, Clement R, Moncrieff J, Montagnani L, Minerbi S, Jarvis PG (2000) Respiration as the main determinant of carbon balance in European forests. Nature 404:861-865

Vitousek P, Ehrlich P, Ehrlich A, Matson P (1986) Human appropriation of the products of photosynthesis. BioScience 36:368-373

Vleeshouwers LM, Verhagen A (2002) Carbon emission and sequestration by agricultural land use: a model study for Europe. Glob Chang Biol 8:519-530

Vuichard N, Viovy N, Ciais P, Soussana JF, Calanca P (2004) Greenhouse gases sources and sinks over European grasslands: first calculations using a process-driven model. Invited oral presentation at the First General Assembly of European Geosciences Union, Nice (France), 29 April 2004

Walter BP, Heimann M, Matthews E (2001) Modeling modern methane emissions from natural wetlands 1. Model description and results. J Geophys Res 106(D24):34189-34206

Weishampel JF, Blair JB, Knox RG, Dubayah R, Clark DB (2000) Volumetric lidar return patterns from an old-growth tropical rainforest canopy. Int J Remote Sens 21:409-415

West TO, Marland G (2002) A synthesis of carbon sequestration, carbon emissions, and net carbon flux in agriculture: comparing tillage practices in the United States. Agric Ecosyst Environ 91:217-232

West TO, Marland G (2003) Net carbon flux from agriculture: carbon emissions, carbon sequestration, crop yield, and land-use change. Biogeochemistry 63:73-83

West TO, McBride AC (2005) The contribution of agricultural lime to carbon dioxide emissions in the United States: dissolution, transport, and net emissions. Agriculture Ecosystems and Environment 108:145-154

Williams M, Shimabukuro YE, Herbert DA, Lacruz SP, Renno C, Rastetter EB (2002) Heterogeneity of soils and vegetation in an eastern Amazonian rain forest: implications for scaling up biomass and production. Ecosystems 5:692-704

Yan X, Cai Z, Ohara T, Akimoto H (2003) Methane emission from rice fields in mainland China: amount and seasonal and spatial distribution. J Geophys Res 108(D16):4505

Zheng X, Han S, Huang Y, Wang Y, Wang M (2004) Re-quantifying the emission factors based on field measurements and estimating the direct $\mathrm{N}_{2} \mathrm{O}$ emission from Chinese croplands. Glob Biogeochem Cycles 18:GB2018

Zhou GS, Wang YH, Jiang YL, Yang ZY (2002) Estimating biomass and net primary production from forest inventory data: a case study of China's Larix forests. For Ecol Manag 169:149-157

Zhou X, Peng CH, Dang Q, Chen J, Parton S (2008) A simulation of temporal and spatial variations in carbon at landscape level: a case study for Lake Abitibi Model Forest in Ontario, Canada. Mitig Adapt Strategies Glob Chang (in press) 